\title{
Human immunoglobulin selection associated with class switch and possible tolerogenic origins for $\mathrm{C} \delta$ class-switched B cells
}

\author{
Nai-Ying Zheng, ${ }^{1}$ Kenneth Wilson, ${ }^{1}$ Xiaojian Wang, ${ }^{1}$ Angela Boston, ${ }^{1}$ Grant Kolar, ${ }^{1}$ \\ Stephen M. Jackson, ${ }^{1}$ Yong-Jun Liu, ${ }^{2}$ Virginia Pascual, ${ }^{3}$ J. Donald Capra, ${ }^{1}$ and Patrick C. Wilson ${ }^{1}$ \\ ${ }^{1}$ Molecular Immunogenetics, Oklahoma Medical Research Foundation, Oklahoma City, Oklahoma, USA. 2MD Anderson Cancer Center, Houston, Texas, USA. \\ ${ }^{3}$ Baylor Institute for Immunology Research, Dallas, Texas, USA.
}

\begin{abstract}
Current paradigms of peripheral B cell selection suggest that autoreactive B cells are controlled by clonal deletion, anergy, and developmental arrest. We report that changes to the human antibody repertoire likely resulting from these mechanisms both for a well-characterized autoreactivity from antibodies encoded by the $V_{H} 4-34$ gene and for other hallmarks of an autoreactive repertoire are apparent mainly for class-switched $B$ cells and not for IgM germinal center, IgM memory, or IgM plasma cells. Other possible indicators of autoreactivity found selected with immunoglobulin class include $\mathrm{J}_{\mathrm{H}} 6$ gene segment usage, increased frequency of $B$ cells with long third hypervariable regions, and distal $\mathrm{J}_{\mathrm{k}}$ gene segment bias. Of particular interest is the finding that $\mathrm{B}$ cells with these same characteristics are selected into the lineage of $B$ cells that have undergone the unusual class switch from constant region $\mathrm{C} \mu$ to $\mathrm{C} \delta(\mathrm{C} \delta$-CS). The $\mathrm{C} \delta$-CS population also displays an increased frequency of charged amino acids localized to the complementarity-determining regions, further suggesting autoreactivity, and evidence is presented that these B cells had undergone extensive receptor editing. Thus, the C $\delta$-CS lineage may be a "sink" for $B$ cells harboring autoreactive specificities in normal humans. A model for a new tolerizing mechanism that could account for the C $\delta$-CS lineage is presented.
\end{abstract}

\section{Introduction}

One of the most prolific topics in immunology today is the mechanism and regulation of Ig class-switch recombination (CSR). In this report, we find that changes to the human Ig repertoire occur mainly in association with class switch. Naive B cells can be induced by antigen encounter and $\mathrm{T}$ cell help to form germinal centers (GCs), ultimately leading to the generation of memory and plasma cells (PCs). Antigen-activated GC precursors differentiate to centroblasts, which rapidly proliferate and initiate the somatic hypermutation process (1-3). Centroblasts differentiate to centrocytes that can undergo CSR from IgM/IgD to secondary classes such as IgG and IgA (4). CSR involves a genetic recombination that deletes all intervening sequence between switch regions, thus permanently juxtaposing the specific variable-diversity-joining (VDJ) region to the various secondary constant (C) regions. Of particular interest to this study is a lineage of $\mathrm{B}$ cells that we refer to as "C $\delta$-CS" for " $C \delta$ class-switched." Unlike normal $C \mu$-versus- $C \delta$ usage involving differential splicing of a single VDJ-C $\mu-C \delta$ transcript, $C \delta$-CS B cells actually undergo class switch from $C \mu$ to $C \delta$ at the genetic level using cryptic switch regions between the $\mathrm{C} \mu$ and $\mathrm{C} \delta$ exons $(5,6)$. C $\delta$-CS GC cells can differentiate into IgDsecreting PCs (7) and memory cells (8) and have the unusual characteristics that they use more than $90 \% \lambda$ light chains (7) and accu-

Nonstandard abbreviations used: antinuclear antigen (ANA); class-switch recombination (CSR); complementarity-determining region (CDR); constant (C); $\mathrm{C} \delta$ class-switched (CS-CS); diversity (D); germinal center (GC); i and/or I (iI); Ig heavy chain joining region (gene) $\left(\mathrm{J}_{\mathrm{H}}\right)$; Ig heavy chain variable region (gene) $\left(\mathrm{V}_{\mathrm{H}}\right)$; Ig $\kappa$ chain joining region (gene) $\left(\mathrm{J}_{\kappa}\right)$; Ig $\kappa$ light chain variable region (gene) $\left(\mathrm{V}_{\kappa}\right)$; joining $(\mathrm{J})$; plasma cell (PC); recombination signal sequence (RSS); third complementaritydetermining region (CDR3); variable (V).

Conflict of interest: The authors have declared that no conflict of interest exists.

Citation for this article: J. Clin. Invest. 113:1188-1201 (2004).

doi:10.1172/JCI200420255. mulate more somatic mutations than any other B cell population (9), and we have shown this population has the highest frequency of receptor-edited heavy chain $\mathrm{V}$ regions (10).

$\mathrm{V}_{\mathrm{H}} 4-34$ gene segments encode natural autoantibodies that recognize the $\mathrm{i}$ and/or I (iI) antigens, which are the glycan "scaffold" for a number of common molecules, including the A, B, O, H, and Lewis blood group antigens and keratan sulfate (11-13). Neoplastic transformation and infections causing proliferation of $\mathrm{V}_{\mathrm{H}} 4-34^{+}$ $\mathrm{B}$ cells can cause pathological cold agglutinin disease. $\mathrm{V}_{\mathrm{H}} 4-34$ also has an enhanced role in a number of autoimmune syndromes, including lupus (14-16). There is also a report of an expanded $\operatorname{IgD}{ }^{-} \mathrm{CD} 27^{\text {high }} \mathrm{B}$ cell population in patients with lupus in which $20 \%$ of the total cells utilized $V_{\mathrm{H}} 4-34$ and another $20 \%$ expressed antibodies encoded by the $V_{H} 4-61$ gene segment (17). Despite the autoimmune potential of $\mathrm{V}_{\mathrm{H}} 4-34$, it is significantly over-represented in developing and naive $\mathrm{B}$ cells because it has the most efficient recombination signal sequence of all human $V_{H}$ genes (18), representing $6-8 \%$ of naive and developing B lymphocytes in normal people $(14,19,20)$. However, there is a powerful counterselection against $\mathrm{V}_{\mathrm{H}} 4-34^{+} \mathrm{B}$ cells in GC cell, memory cell, and PC populations, and $\mathrm{V}_{\mathrm{H}} 4-34^{+}$antibodies are difficult to detect in most serum samples. There is no other naturally encoded antibody or $\mathrm{V}_{\mathrm{H}}$ gene that is known to undergo such a profound change in repertoire representation, thus analysis of $\mathrm{V}_{\mathrm{H}} 4-34$ usage provides an excellent model of B cell selection in normal humans.

$\mathrm{B}$ cells harboring receptors that bind to our own tissues are normally controlled by clonal deletion or by editing of their B cell receptor through further $V$ gene recombination $(21,22)$. Various related processes also alter the normal immunogenesis of autoreactive $B$ cells, including induction of anergy (23), exclusion from B cell follicles and developmental arrest $(24,25)$, and autoimmune "ignorance" (26). It has recently been found that $20 \%$ of B cells 
emerging from the bone marrow still retain some degree of autospecificity that must be controlled by peripheral selective mechanisms (27). We initiated this study to characterize the dynamics of selection of peripheral B cells in normal humans. Our study includes a comprehensive characterization of peripheral B cell selection involving cytometric analysis of 25 normal donors, and $86 \mathrm{~V}$ gene libraries from 38 donors totaling over 4,200 V gene sequences from various peripheral B cell differentiations (Table 1). Various libraries isolated from particular donors were analyzed for selection against use of the $\mathrm{V}_{\mathrm{H}} 4-34$ gene segment in addition to several other well-characterized hallmarks typical of an autoimmune or coun- terselected repertoire and for evidence that the cells were subjected to receptor editing during development. The most significant finding was that changes to the $\operatorname{Ig} \mathrm{V}$ gene repertoire in the periphery occur mainly in association with the Ig CSR process rather than just with differentiation to GC cells, memory cells, and PCs. Because the various features of the Ig repertoire, and particularly those features associated with autoimmunity, were selected in association with B cell class rather than B cell compartment, we conclude that although avoidance of autoreactive IgM-utilizing B cells must certainly occur, the prevailing gross effect of peripheral selective mechanisms may be avoidance of secondary class-switched B cells with

Table 1

Donors, populations, sequences, and clones analyzed

\begin{tabular}{|c|c|c|c|c|c|c|c|c|c|c|c|c|c|}
\hline Donor & Population & Sequences ${ }^{A}$ & $V_{H} 4^{B}$ & $\mathrm{~J}_{H^{B}}$ & CDR3 $^{B}$ & $\begin{array}{l}\text { Charged } \\
\text { residues }^{B}\end{array}$ & Donor & Population ${ }^{B}$ S & Sequence & $e s^{A} V_{H} 4^{B}$ & $\mathrm{~J}_{\mathrm{H}^{\mathrm{B}}}$ & $\mathrm{CDR}^{\mathrm{B}}$ & $\begin{array}{l}\text { Charged } \\
\text { residues }^{B}\end{array}$ \\
\hline \multirow[t]{5}{*}{1} & Naive & 125 & * & * & * & * & 14 & $\operatorname{IgM} G C$ & 17 & * & * & * & * \\
\hline & $\lg M G C$ & 128 & * & * & * & * & & $\lg G \mathrm{GC}$ & 25 & * & * & * & * \\
\hline & IgM Mem & 137 & * & * & * & * & & C $\delta$-CS GC & 19 & * & * & & \\
\hline & $\operatorname{lgG~GC}$ & 217 & * & * & * & * & 15 & IgM Mem & 29 & * & * & * & * \\
\hline & IgG Mem & 108 & * & * & * & * & & IgG Mem & 23 & * & * & * & * \\
\hline \multirow[t]{7}{*}{2} & Naive & 127 & * & * & * & & 16 & IgG Mem & 20 & * & * & * & * \\
\hline & Pre-GC & 124 & * & * & * & & 17 & IgG Mem & 24 & * & * & * & * \\
\hline & Pre-GC V $V_{H} 1$ & 19 & & * & & & 18 & $\mathrm{C} \delta$-CS GC & 63 & * & * & * & * \\
\hline & $\operatorname{IgM} \mathrm{GC}$ & 93 & * & * & * & & & C $\delta$-CS GC (scPCR) & 78 & * & * & & \\
\hline & $\lg G \mathrm{GC}$ & 128 & * & * & * & & & $\mathrm{C} \delta-\mathrm{CS} \mathrm{V}_{\mathrm{H}} 3$ & 46 & & * & & \\
\hline & C $\delta$-CS GC & 65 & * & * & * & * & 19 & $\mathrm{C} \delta-\mathrm{CS} \mathrm{GC}$ & 26 & * & * & * & * \\
\hline & $\mathrm{C} \delta-\mathrm{CS} G C \mathrm{~V}_{\mathrm{H}} 1$ & 26 & & * & & & & C $\delta$-CS GC (scPCR) & 35 & * & * & & \\
\hline \multirow[t]{3}{*}{3} & $\lg M P C$ & 81 & * & * & * & * & & $\mathrm{C} \delta-\mathrm{CS} \mathrm{V}_{\mathrm{H}} 3$ & 24 & & * & & \\
\hline & $\lg G \mathrm{PC}$ & 76 & * & * & * & * & 20 & $\mathrm{C} \delta$-CS GC & 15 & * & * & * & \\
\hline & C $\delta$-CS PC & 87 & * & * & * & * & 21 & Naive & 22 & * & * & * & * \\
\hline \multirow[t]{3}{*}{4} & C $\delta-C S ~ G C$ & 60 & * & * & * & * & 22 & Naive & 24 & * & * & * & * \\
\hline & $\mathrm{C} \delta-\mathrm{CS}$ GC V $\mathrm{H}_{\mathrm{H}} 1$ & 34 & & * & & & & IgM Mem & 29 & * & * & * & * \\
\hline & Total B cell IgD & 73 & & $\mathrm{rcom}$ & arison or & & 23 & Naive & 24 & * & * & * & * \\
\hline \multirow[t]{6}{*}{5} & Naive & 16 & * & * & * & * & 24 & Naive & 51 & * & * & * & * \\
\hline & Pre-GC & 23 & * & * & * & * & & IgM Mem & 30 & * & * & * & * \\
\hline & $\operatorname{IgM} G C$ & 19 & * & * & * & * & 25 & Naive & 50 & * & * & * & * \\
\hline & $\lg G \mathrm{GC}$ & 18 & * & * & * & * & 26 & Naive $V_{H} 1$ & 24 & & * & * & * \\
\hline & IgG Mem & 22 & * & * & * & * & & $\lg G \mathrm{GC} V_{H} 1$ & 29 & & * & * & * \\
\hline & C $\delta-C S ~ G C$ & 19 & * & * & * & * & & $\mathrm{C} \delta-\mathrm{CS} \mathrm{V}_{\mathrm{H}} 3$ & 30 & & * & * & * \\
\hline 6 & IgG Mem & 16 & * & * & * & * & & $\mathrm{C} \delta$-CS V 1 & 55 & & * & * & * \\
\hline \multirow[t]{2}{*}{7} & IgM Mem & 15 & * & * & * & * & 27 & IgM Mem & 36 & * & * & * & * \\
\hline & IgG Mem & 15 & * & * & * & * & 28 & IgM Mem & 29 & * & * & * & * \\
\hline \multirow[t]{2}{*}{8} & $\operatorname{lgG~GC}$ & 52 & * & * & * & * & 29 & IgM Mem & 15 & * & * & & \\
\hline & $\lg G P C$ & 65 & * & * & * & * & 30 & IgM GC & 31 & & * & * & \\
\hline \multirow[t]{2}{*}{9} & IgM Mem & 22 & * & * & * & * & & $\mathrm{C} \delta-\mathrm{CS} V_{\mathrm{H}} 1$ & 48 & & * & * & * \\
\hline & IgG Mem & 23 & * & * & * & * & & $\mathrm{C} \delta-\mathrm{CS} V_{\mathrm{H}} 3$ & 27 & & * & & \\
\hline \multirow[t]{4}{*}{10} & Naive & 32 & * & * & * & * & 31 & Naive $\kappa$ & 56 & $\kappa$ analysis & & & \\
\hline & $\operatorname{lgM}$ GC & 88 & * & * & * & * & & $\mathrm{C} \delta-\mathrm{CS} \kappa$ & 44 & & & & \\
\hline & IgM Mem & 60 & * & * & * & * & 32 & Naive $\kappa$ & 55 & & & & \\
\hline & IgM PC & 26 & * & * & * & * & 33 & Naive $\kappa$ & 50 & & & & \\
\hline \multirow[t]{2}{*}{11} & Pre-GC & 69 & * & * & * & * & & $\mathrm{C} \delta-\mathrm{CS} \kappa$ & 59 & & & & \\
\hline & C $\delta$-CS GC & 257 & * & * & * & * & 34 & $\operatorname{lgG}$ Mem $\kappa$ & 25 & & & & \\
\hline \multirow[t]{4}{*}{12} & IgM GC & 58 & * & * & * & * & 35 & IgG Mem $\kappa$ & 24 & & & & \\
\hline & $\lg G \mathrm{GC}$ & 42 & * & * & * & * & 36 & Mem $\kappa$ & 24 & & & & \\
\hline & C $\delta$-CS GC & 34 & * & * & * & * & & $\mathrm{C} \delta$-CS $\kappa$ & 25 & & & & \\
\hline & $\mathrm{C} \delta$-CS GC V $\mathrm{V}_{\mathrm{H}} 1$ & 23 & & * & & & 37 & Mem к & 21 & & & & \\
\hline \multirow[t]{3}{*}{13} & $\lg M G C$ & 14 & * & * & * & * & & $\mathrm{C} \delta-\mathrm{CS} \kappa$ & 24 & & & & \\
\hline & C $\delta$-CS GC & 21 & * & * & * & * & 38 & $\mathrm{C} \delta-\mathrm{CS} \kappa$ & 59 & & & & \\
\hline & & & & & & & Total & & 4221 & & & & \\
\hline
\end{tabular}

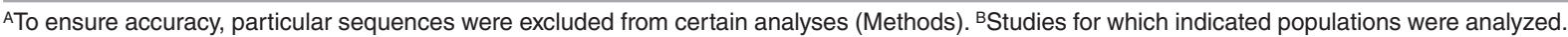
Asterisks indicate the studies in which the various populations were included. sc, single-cell. 
autoreactive specificity. In addition, the C $\delta$-CS lineage of B cells appears to be a "sink" for autoreactive B cells in normal humans. These findings provide an important step toward understanding the homeostasis between antibody-mediated immunity and dangerous autoimmunity in normal humans.

\section{Methods}

B lymphocyte isolation and cytometry. B lymphocytes were isolated from human tonsils obtained during routine tonsillectomy following established NIH guidelines with proper institutional board approval or from the buffy coat component from $500 \mathrm{ml}$ of freshly donated peripheral blood purchased from the Oklahoma Blood Institute (Oklahoma City, Oklahoma, USA). B cell purification by magnetic beads, staining, and sorting were performed as described previously $(3,7,28)$, except for use of anti-CD27 to sort or identify memory B cells as described (29). The 9G4 rat mAb was purified from hybridoma supernatants using protein G-Sepharose columns (Amersham Biosciences, Arlington Heights, Illinois, USA) and was used in conjunction with PharMingen FITC-conjugated anti-rat $V_{\kappa}$ protein (PharMingen, San Diego, California, USA).

$\mathrm{V}_{\mathrm{H}} 4$ library population $n$ values are indicated in Table 1 . The populations for which $\mathrm{V}$ gene libraries were generated included naive $\left(\mathrm{IgD}^{+} \mathrm{IgM}^{+} \mathrm{CD} 38^{-}\right.$[tonsil] or $\mathrm{CD}^{2} 7^{-}$[blood]), pre-GC $\left(\mathrm{IgD}^{+} \mathrm{IgM}^{+} \mathrm{CD} 38^{+}\right)$, GC $\left(\mathrm{IgD}^{-} \mathrm{CD} 38^{+}\right.$, also $\mathrm{CD} 27^{-}$for donors 13 and $14)$, centroblast $\left(\mathrm{IgD}^{-} \mathrm{CD} 38^{+} \mathrm{CD} 77^{+}\right)$, centrocyte $\left(\mathrm{IgD}^{-} \mathrm{CD} 38^{+} \mathrm{CD} 77^{-}\right)$, memory $\left(\mathrm{IgD}^{-} \mathrm{CD} 38^{-} \mathrm{CD} 27^{+}\right)$, PC (low density, CD38 $8^{\text {high }} \mathrm{CD} 20^{\text {low }}$ ), and $\mathrm{C} \delta$-CS GC $\left(\operatorname{IgD}^{+} \operatorname{IgM}{ }^{-} \mathrm{CD} 38^{+}\right)$. Detailed phenotypes and isolation procedures of all populations have been published previously $(3,4$, $7,9,30-32)$. It is notable that the $\operatorname{IgM~GC~}\left(\operatorname{IgD}^{-} \mathrm{CD} 38^{+}\right)$fraction can contain a minor portion of recent bone marrow immigrants (33), and a potential counterpart to the murine marginal zone $B$ cell has been recently described that would also fall into this category (34).

Immunohistochemistry. Sections $5 \mu \mathrm{m}$ in thickness from "snapfrozen" tonsils were cut and fixed with acetone. For three-step IgM analysis (Figure 1C), incubation with primary antibody $9 \mathrm{G} 4$ (anti- $\left.\mathrm{V}_{\mathrm{H}} 4-34\right)$ was followed by incubation with FITC-conjugated rabbit anti-rat IgG (Sigma-Aldrich, St. Louis, Missouri, USA), and then biotinylated goat anti-human IgM (Jackson ImmunoResearch, West Grove, Pennsylvania, USA) followed by Texas red streptavidin (Jackson ImmunoResearch) and finally aminomethylcoumarin acetate-conjugated donkey anti-human IgG (Jackson ImmunoResearch). Analyses were made with a Zeiss Axioplan fluorescent microscope in the Oklahoma Medical Research Foundation imaging facility.

Sequencing Ig VDJ and VJ gene transcripts. For analyses of V gene repertoires presented in Figures 2, 3, 4, and 5 and Table 2, all PCR primer sequences are listed in Supplemental Table 1 (supplemental material available at http://www.jci.org/cgi/content/full/113/ $8 / 1188 / D C 1)$ or as previously described $(10,28)$. Isolation of RNA, production of CDNA, and generation and screening of the various $\mathrm{V}$ gene libraries was done as described previously (10). An alternate $\mathrm{V}_{\mathrm{H}} 4$ gene primer (VH4P2) was used for several libraries to ensure changes in the repertoire were not introduced by primer bias. PCR products were cloned using the TA Cloning Kit or the TOPO-TA Cloning Kit (Invitrogen, Carlsbad, California, USA). Individual colonies from the various $V$ gene libraries were randomly picked for preparation of plasmid DNA using the miniprep kit (Qiagen, Valencia, California, USA) and sequencing at the Oklahoma Medical Research Foundation Sequencing Facility using either Applied Biosystems ABI-377 or ABI-3730
DNA sequencers. All V gene sequences were analyzed using "inhouse" analysis software and the National Center for Biotechnology Information IgBlast server (http://www.ncbi.nlm.nih. gov/igblast/) or the Immunogenetics server (http://imgt.cines. $\mathrm{fr} /$ textes/vquest/) (35). Statistical analyses were performed using Microsoft Excel (Redmond, Washington, USA).

Background mutation frequencies were determined to average 0.79 base mismatches per $1,000 \mathrm{bp}$ based on analysis of a section of $\mathrm{C}$-region gene sequence isolated as part of each cDNA clone analyzed. Sequences of questionable quality for incorporated mutations were analyzed for excessive C-region mutations above background and if above background in the $\mathrm{C}$ region they were excluded from analyses of charged residues, somatic mutation, and iI antigen-binding residue analysis. Sequences in which hybrid $V$ genes or other ambiguities were included for various analyses only if they were judged to have unique long third complementarity-determining region (CDR3) segments; that is, a sequence with an ambiguous $\mathrm{J}$ region identity but a clearly unique VDJ junction (CDR3) was included for analysis of $\mathrm{V}$ gene usage but not J gene usage. Populations isolated as naive were given greater scrutiny and only accepted as "naive" if one or zero mutations were detected in a V gene. Clonally related sequences were included if they differed by more than one mutation and thus could be considered differentially somatically mutated in order to represent the "true" repertoire. In order to determine if inclusion of clonal expansions would affect the outcome of this study, each analysis was also done in which only $\mathrm{V}$ genes with unique CDR3s were considered. These analyses generated the same conclusions as the analyses presented that included all clones. Clones with identical CDR3s and differing by only one or no mutations were not included because they may have represented dual cloning of a single PCR amplification product, although inclusion would have been unsubstantial (tested empirically).

Analysis of $V_{K} 4-1$ to $J_{K} 2$ for receptor editing. Genomic DNA was isolated using DNAzol reagent (Molecular Center Research Inc., Cincinnati, Ohio, USA) from naive $\left(\mathrm{IgM}^{+} \mathrm{IgD}^{+} \mathrm{CD} 38^{-} \mathrm{CD} 27^{-}\right)$, C $\delta$-CS $\left(\mathrm{IgM}^{-} \mathrm{IgD} \mathrm{CD}^{+} \mathrm{C} 8^{+}\right)$, and memory $\left(\mathrm{IgD}^{-} \mathrm{CD} 38^{-} \mathrm{CD} 27^{+}\right) \mathrm{B}$ cells. PCR of $\mathrm{V}_{\mathrm{K}} 4$-to- $\mathrm{J}_{\mathrm{K}} 2$ rearrangements and recombination signal sequence (RSS) junctions were performed using the primer pairs (Supplemental Table 1) illustrated in Figure 5B. PCR reactions were done using Qiagen HotStar Taq polymerase with the following cycle conditions: 15 minutes at $95^{\circ} \mathrm{C}$, then 30 cycles of $95^{\circ} \mathrm{C}$ for 30 seconds, $60^{\circ} \mathrm{C}$ for 30 seconds, and $72^{\circ} \mathrm{C}$ for 1 minute, with a final 10 -minute extension at $72^{\circ} \mathrm{C}$. Ratios of genomic DNA isolates were first normalized for the abundance of $\mathrm{V}_{\mathrm{K}} 4-$ to- $\mathrm{J}_{\mathrm{K}} 2$ rearrangements. Normalization based on presence of the $\mathrm{V}_{\mathrm{K}} 4-1$-to- $\mathrm{J}_{\mathrm{K}} 2$ rearrangement frequency also accounts for any loss of the RSS junctions due to the $\kappa$-deleting element rearrangement (36) that often accompanies receptor editing, because both the rearrangement and the junction would be lost with the $\kappa$ locus. Comparison with memory B cells as well as naive $\mathrm{B}$ cells controls for the possibility that the increased RSS junctions are from epigenic (recombination circle) DNA due to previous rearrangement that might be detectable in the naive cells after recent immigration from the bone marrow.

Antibody expression and testing for $9 G 4$ reactivity and cold agglutination. Transcripts of antibody $\mathrm{V}_{\mathrm{H}}$ genes were cloned into an expression vector containing human IgG and were cotransfected with an FS7- $\mathrm{KV}$ gene into the 293A fibroblast cell line using Roche FuGene transfection reagent following the manufacturer's suggested protocol (Roche Diagnostics Corp., Indianapolis, Indiana, USA). The FS7 antibody is a classic cold agglutinin encoded by $\mathrm{V}_{\mathrm{H}} 4-34$, and the FS7- $\kappa$ 
A

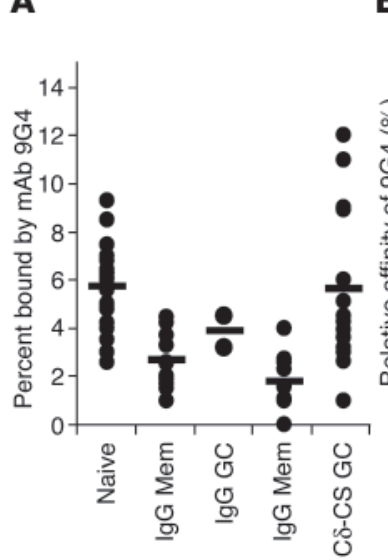

c

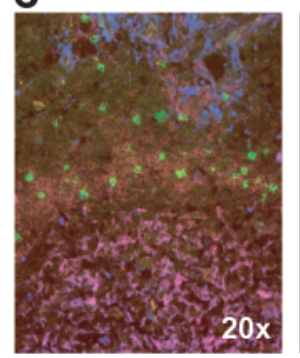

B

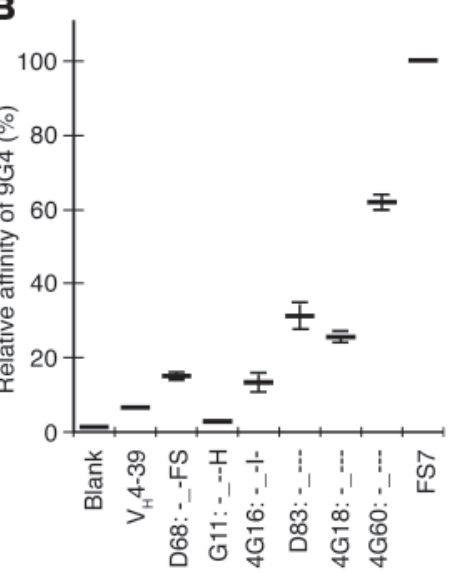

D

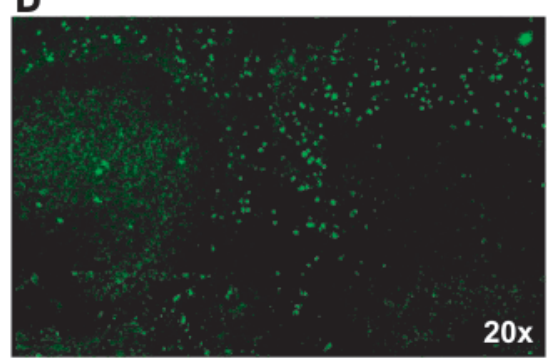

gene is permissive for expression of 9G4-reactive antibodies (37). Transfected 293A cells were allowed to secrete antibodies in serumfree DMEM supplemented with $1 \%$ Nutridoma-SP (Roche) for 5 days. Antibodies were purified using a protein G-Sepharose column (Amersham Biosciences). Antibody concentrations were determined by ELISA and Western blot and were adjusted to $1 \mu \mathrm{g} / \mathrm{ml}$. Reactivity to the $9 \mathrm{G} 4$ antibody was determined by capture ELISA. ELISA plates were coated with anti-rat IgG (Jackson ImmunoResearch), followed by $9 \mathrm{G} 4 \mathrm{mAb}$, and then were incubated with the various expressed $\mathrm{V}_{\mathrm{H}} / \mathrm{FS}_{\mathrm{\kappa}}$ antibodies in serial threefold dilutions. Bound antibody was detected using biotin-anti-human IgG (Jackson ImmunoResearch) followed by steptavidin-HRP (Jackson ImmunoResearch) and development with HRP substrate (BioRad, Hercules, California, USA). Analysis of cold agglutination was performed by Coomb's assay using commercially available reagents following the manufacturer's protocol (Immucor Inc., Norcross, Georgia, USA).

Single-cell RT-PCR. IgD ${ }^{+} \operatorname{IgM}{ }^{-} \mathrm{CD} 38^{+} \mathrm{C} \delta$-CS B cells were bulk sorted from the $\mathrm{B}$ cell fraction of isolated human tonsils using a Cytomation MoFlo cytometer as described above. The bulk-sorted C $\delta$-CS cells were then re-sorted into 96-well PCR plates. $V_{H} 4$ gene libraries were then prepared from the unused bulk-sorted cells and single-cell analysis was performed on the plates for comparison. Single-cell RT-PCR was performed as described previously (27). Individual $\mathrm{V}$ genes were cloned and sequenced as described above.

\section{Results}

Selection of the naturally autoreactive $V_{H} 4-34$ gene segment is evident by analysis with the $9 \mathrm{G} 4 \mathrm{mAb}$. In order to gain insight into the dynamics of tolerance to autoantibody-producing B cells in humans, we analyzed $V_{\mathrm{H}} 4-34$ gene segment usage in various mature $B$ cell subpopulations. The mAb 9G4 is highly specific for Ig encoded by the $\mathrm{V}_{\mathrm{H}} 4-34$ gene and no other, but as described below it is highly sensitive to incorporated somatic mutations. The predicted outcome of this

\section{Figure 1}

Immunohistochemical and cytometric analysis of $\mathrm{V}_{\mathrm{H}} 4-34^{+}$antibody expression. (A) Cytometric analysis to determine the percentage of naive ( 24 donors), $\operatorname{lgM}^{+} \mathrm{GC}$ ( 2 donors), IgM+ memory (Mem) cells (11 donors), IgG+ memory cells (12 donors), and C $\delta$-CS GC cells (14 donors) utilizing $\mathrm{V}_{\mathrm{H}} 4-34$ (mAb $9 \mathrm{G} 4^{+}$). Bars indicate mean. (B) Detection of $\mathrm{V}_{\mathrm{H}} 4-34-e n c o d e d$ antibodies by $9 \mathrm{G} 4$ is inhibited by somatic hypermutation. Relative binding by $9 \mathrm{G} 4$ was compared by ELISA for an unmutated $\mathrm{V}_{\mathrm{H}} 4$-34-encoded antibody (FS7) plus six $\mathrm{V}_{\mathrm{H}} 4$-34-encoded heavy chains harboring somatic mutations and a non- $\mathrm{V}_{\mathrm{H}} 4-34$ control antibody $\left(\mathrm{V}_{\mathrm{H}} 4-39\right)$. Dashes adjacent to the clone names indicate mutations to the 9G4 mAb epitope at amino acids W7, A23, V24, and Y25, and replacements are indicated by single-digit amino acid code. The mean and SD of three assays are indicated. (C) Micrograph of a human tonsil section stained with anti-lgM (red), anti-lgG (blue), and anti- $\mathrm{V}_{\mathrm{H}} 4-34$ (9G4 mAb, green). The field is bisected by a follicular mantle (naive B cells) surrounding a $\mathrm{GC}$ at the bottom. Individual naive cells were scored for frequency of $V_{H} 4-34$ usage from 4 donors $(7 \% \pm 1 \%$ SD were $\left.\mathrm{V}_{\mathrm{H}} 4-34^{+}\right)$. (D) Micrograph of a tonsil section stained with $9 \mathrm{G} 4 \mathrm{mAb}$ (anti- $\mathrm{V}_{\mathrm{H}} 4-34$, green). Two GCs are evident from the mantles of $9 \mathrm{G} 4^{+}$ stained naive cells. The GC on the left is made up of an oligoclonal expansion of $\mathrm{V}_{\mathrm{H}} 4-34$-utilizing $\left(9 \mathrm{G} 4^{+}\right)$cells with $9 \mathrm{G} 4^{\text {bright }}$ plasmablasts differentiating within the $\mathrm{GC}$ proper, indicating that $\mathrm{V}_{\mathrm{H}} 4-34^{+} \mathrm{B}$ cells can contribute to immune reactions. The GC on the right is $9 \mathrm{G} 4^{-}$.

analysis was that $\mathrm{B}$ lymphocytes expressing the $\mathrm{V}_{\mathrm{H}} 4-34$ gene would be excluded after the highly selective environment of the GC reaction. Evidence of this selection in GCs had been previously reported using the $9 \mathrm{G} 4 \mathrm{mAb}(14)$. Consistent with previous studies, analysis of $\mathrm{B}$ cells from 24 donors (Figure $1 \mathrm{~A}$ ) by flow cytometry found that $6 \%$ of all naive $B$ cells utilize the $V_{H} 4-34$ gene $(6 \% \pm 2 \% \mathrm{SD})$. Given that there are approximately 50 functional $V_{H}$ genes, the $\mathrm{V}_{\mathrm{H}} 4-34$ gene is used at threefold the random frequency. Also consistent with previous analyses, $3 \% \pm 1 \%$ of $\operatorname{IgM}^{+}$memory cells (11 donors) and $3.9 \% \pm 1 \%$ of $\operatorname{IgM}^{+}$GCs ( 2 donors) were $9 \mathrm{G}^{+}$. Analysis of 12 donor blood and tonsil specimens found that only $1.8 \% \pm 1 \%$ of $\mathrm{IgG}^{+}$memory B cells were "encoded" by $\mathrm{V}_{\mathrm{H}} 4-34$, which is significantly fewer than the $\operatorname{IgM}^{+}$cells by analysis of the variance of means between donors by Student's $t$ test $(P<0.05)$. Interestingly, in results averaged from 14 tonsil specimens, $6 \% \pm 3 \%$ of the unusual C $\delta$-CS GC B cells utilized $V_{H} 4-34$. Because this population accumulates the most somatic hypermutations of all B cells (ref. 9 and Table 3 ), and, as discussed below, binding by the 9G4 antibody is highly sensitive to somatic mutations, detection of $6 \%$ of the cells as $\mathrm{V}_{\mathrm{H}} 4-34^{+}$likely indicated a much higher frequency of $\mathrm{V}_{\mathrm{H}} 4-34^{+}$utilization, which did indeed turn out to be the case (see below). Thus, this analysis gave the first indication that the $\mathrm{C} \delta$-CS lineage might differentiate from $B$ cells expressing natural autoreactivities in normal humans.

In conclusion, analysis with the $9 \mathrm{G} 4 \mathrm{mAb}$ demonstrated that $\mathrm{V}_{\mathrm{H}}$ 4-34 usage is powerfully counterselected from IgG-utilizing B cells and, unlike the results in previous reports, is significantly greater in $\mathrm{IgM}^{+}$memory or $\mathrm{IgM}^{+} \mathrm{GC}$ cells than the $\mathrm{IgG}^{+}$cells. In addition, analysis with the $9 \mathrm{G} 4 \mathrm{mAb}$ would indicate counterselection between naive and $\operatorname{IgM}^{+} \mathrm{GC}$ and memory cells. The $9 \mathrm{G} 4 \mathrm{mAb}$ does not bind to all $\mathrm{V}_{\mathrm{H}} 4-34$-encoded antibodies (37), and there is evidence that it is inhibited by accumulation of somatic mutations. Therefore, we were concerned that analyses of $\mathrm{V}_{\mathrm{H}} 4-34$ usage as detected by $9 \mathrm{G} 4$ binding both in our own studies reported above 
and by other groups previously might underestimate the somatically mutated populations. Indeed, expression of six different mutated $V_{\mathrm{H}}$ 4-34-encoded VDJ transcripts with a "permissive" light chain were significantly less reactive to $9 \mathrm{G} 4$ than to a germline $\mathrm{V}_{\mathrm{H}} 4$ 34 antibody (Figure 1B). The epitope of the $9 \mathrm{G} 4 \mathrm{mAb}$ includes a tryptophan residue (W) at position 7 , and alanine, valine, and tyrosine residues (AVY) at positions 23-25 (37). Clones having mutations directly to the W and AVY positions are indicated in Figure $1 \mathrm{~B}$ by dashes (identity to W AVY = "-_---“), and replacements are identified by replacement of the dashes with the amino acid single-letter code. Three of these antibodies harbored mutations directly to the 9G4-bound epitope, and three had no mutations to the epitope directly but were otherwise mutated, suggesting that 9G4 binding is sensitive to mutations both directly and outside of the defined epitope. Assuming that 9G4 affinity translates directly to detection by flow cytometry, this sensitivity could account for the reduced 9G4 binding in all somatically mutated populations reported both here and previously (14). In addition, a comparison of 9G4 detection of $\mathrm{V}_{\mathrm{H}}$ 4-34 usage with $\mathrm{V}_{\mathrm{H}} 4$ gene repertoires generated by random sequencing of the same populations demonstrated that only one half to three quarters of somatically mutated $\mathrm{V}_{\mathrm{H}} 4-34$ gene-utilizing B cells are detectable by $9 \mathrm{G} 4$ staining (data incorporated into Figures 1 and 2). In conclusion, there appears to be selection of the $\mathrm{V}_{\mathrm{H}}$ 4-34 gene in association with class switch more than with $\mathrm{B}$ cell compartment. However, because of the caveat that 9G4 antibody binding is highly sensitive to somatic mutations, we initiated a more accurate analysis of $\mathrm{V}_{\mathrm{H}}$ 4-34 selection using random sequencing.

Analysis of the $V_{H} 4$ gene repertoire indicates that selection of the autoreactive $V_{H}$ 4-34 gene segment is associated mainly with class switch. $V_{\mathrm{H}}$ 4-34 gene segment utilization was analyzed relative to that of the other nine $V_{\mathrm{H}} 4$ family gene segments by random sequencing to provide a more accurate and comprehensive analysis of the selection of this gene segment than the cytometric and histological studies provided. $A V_{H}$ gene family is defined as all $V_{H}$ genes (totaling 50) having greater than $90 \%$ similar nucleotides (38). Comparison of $\mathrm{V}_{\mathrm{H}} 4$-34 usage only to other $\mathrm{V}_{\mathrm{H}} 4$ family genes allowed a more manageable and quantitative analysis, as all $\mathrm{V}_{\mathrm{H}} 4 \mathrm{cDNA}$ molecules can be similarly PCR amplified by a single nondegenerate priming site in the $V_{H} 4$ leader region. Sixty-one libraries of $V_{H} 4$ gene family VDJ rearrangements were generated by random cloning of RT-PCRamplified transcripts from various B cell subpopulations sorted by cytometry from 30 subjects. As indicated in Table 1 and Supplemental Figure 1, one to six B cell populations were isolated from each donor. Figure $2 \mathrm{~A}$ depicts the selection of $\mathrm{V}_{\mathrm{H}} 4-34$ gene usage in various populations sorted from two donors typical of the selection of this gene. Similar analysis of all donors is provided in Supplemental Figure 1 and means with standard deviation (SD) are provided in Table 2. As depicted by the error bars (SD) of Figure 2, A and B, and by the comparison of all patients for $\mathrm{V}_{\mathrm{H}}$ 4-34 use in Supplemental Figure 1, there was great variation between individual donors for $\mathrm{V}_{\mathrm{H}} 4-34$ gene segment utilization probably due to different immunological histories and different genetic backgrounds. This deviation demonstrates the need for sufficient $n$ values to allow consideration of variance in analyses of human B cell repertoires. Despite the deviation in the overall frequency of $\mathrm{V}_{\mathrm{H}} 4-34$ usage between donors, $\mathrm{V}_{\mathrm{H}} 4-34$ was typically used consistently between naive and secondary $\operatorname{IgM}$ populations (pre-GC, GC, memory, and PC), but at double the frequency in the IgM B cell subsets over the IgG populations. On average, $V_{H} 4-34$ was over-represented in naive B cells $(37 \% \pm 10 \%$ from nine donors,
Figure $2 \mathrm{~B}$ ) and was used consistently in all other B cell populations that had not undergone class switch, including $40 \% \pm 29 \%$ of $\mathrm{V}_{\mathrm{H}} 4$ transcripts from IgM ${ }^{+}$pre-GC cells (three donors), $43 \% \pm 26 \%$ of $\mathrm{V}_{\mathrm{H}} 4$ transcripts from IgM+ $\mathrm{GC}^{+}$cells (six donors), $28 \% \pm 24 \%$ of $\operatorname{IgM}^{+}$memory transcripts (ten donors), and $46 \% \pm 21 \%$ of $\operatorname{IgM}^{+} \mathrm{PC}$ transcripts (two donors). In contrast, B cells utilizing $\mathrm{V}_{\mathrm{H}} 4-34$ were stringently counterselected from IgG populations, including IgG GC (mean $=11 \% \pm 8 \%$; six donors), and IgG memory $(12 \% \pm 8 \%$; eight donors) or IgG PC ( $20 \% \pm 5 \%$; two donors). Consistent with the flow cytometry analyses, $\mathrm{V}_{\mathrm{H}} 4-34$-utilizing $\mathrm{B}$ cells were highly enriched in the unusual $\mathrm{C} \delta$-CS populations, including GC $(65 \% \pm 23 \%$; ten donors) and a single C $\delta$-CS PC population (58\%). It is notable that Student's $t$-test comparisons did not demonstrate statistically significant differences between the various IgM naive, GC, memory, and PC populations, but showed they were all significantly different from the IgG populations with probabilities significant at least at the level of $P<0.05$. $\mathrm{IgG}^{+} \mathrm{GC}$, memory, and PC populations were also statistically similar. $V_{\mathrm{H}} 4-34$ frequency in the $\mathrm{C} \delta$-CS lineage was different from that of all other $\mathrm{B}$ cell populations to at least the level of $P<0.005$. It is notable that loss of $V_{\mathrm{H}} 4-34$ utilization in the IgG populations was compensated for mainly by increases in $\mathrm{V}_{\mathrm{H}} 4-39$ and $\mathrm{V}_{\mathrm{H}} 4-59$, which are the next two J-distal $\mathrm{V}_{\mathrm{H}} 4$ family gene segments in the $\mathrm{V}_{\mathrm{H}}$ locus (Table 2). Certain other $\mathrm{V}_{\mathrm{H}} 4$ genes $\left(\mathrm{V}_{\mathrm{H}} 4-31, \mathrm{~V}_{\mathrm{H}} 4-39, \mathrm{~V}_{\mathrm{H}} 4-59\right.$, and $\left.\mathrm{V}_{\mathrm{H}} 4-61\right)$ displayed significant increases or reductions in particular donor populations, but not in a consistent fashion.

Reorganization of $\mathrm{V}_{\mathrm{H}} 4-34$ usage by Ig class demonstrates the highly significant association of $\mathrm{V}_{\mathrm{H}} 4-34$ selection solely with class switch (see $P$ values, Figure $2 \mathrm{C}$ ). There is stringent selection against $\mathrm{V}_{\mathrm{H}} 4-34^{+} \mathrm{B}$ cells when naive or secondary IgM B cells undergo class switch to IgG (naive, $37 \% \pm 10 \%$; secondary $\operatorname{IgM}, 36 \% \pm 25 \%$; $\operatorname{IgG}$, $13 \% \pm 8 \%$ ), and there is selection of $\mathrm{V}_{\mathrm{H}} 4-34$-utilizing $\mathrm{B}$ cells into the $\mathrm{C} \delta$-CS lineage $(64 \% \pm 22 \%)$. In conclusion, a more accurate and extensive analysis of $\mathrm{V}_{\mathrm{H}}$ 4-34 gene usage by cDNA sequencing indicates that peripheral differentiation or progression through a GC reaction of $\operatorname{IgM}^{+} B$ cells to any other stage does not effect $V_{H} 4-34$ usage. Selection of $B$ cells using this naturally autoreactive $V_{H}$ gene is only apparent in association with Ig class switch.

Correspondence between PCR/sequencing data, immunohistochemistry, cytometry, and single-cell PCR analysis. As described above, the 9G4 antibody binds with high affinity to unmutated $\mathrm{V}_{\mathrm{H}} 4-34$ geneencoded antibodies as found on naive B cells. In order to control for the quantitative capacity of the analyses performed with a different technology, we stained tonsil tissue sections from four donors to count naive cells expressing $\mathrm{V}_{\mathrm{H}} 4$-34-encoded Ig usage $\left(9 \mathrm{G}^{+}\right)$(two donors are presented in Figure 1, C and D). The tissue section in Figure $1 \mathrm{C}$ has a clearly defined $\mathrm{B}$ cell follicular mantle stained with anti-IgM (red) arcing through the center of the image, over a GC at the bottom that is purple due to staining of the follicular dendritic cell network coated with captured IgM (red) and IgG (blue) antibodies. It is notable that unlike a previous report in which no GCs could be found that were made up from expansions of $\mathrm{V}_{\mathrm{H}} 4-34^{+}$cell populations (14), we readily found $9 \mathrm{G}^{+} \mathrm{GCs}$ in tonsil specimens from all donors analyzed. An example of a $\mathrm{V}_{\mathrm{H}} 4-34^{+} \mathrm{GC}$ and $\mathrm{V}_{\mathrm{H}} 4-34^{-} \mathrm{GC}$ in the same microscopic field is presented in Figure 1D. There are also 9G4 $4^{\text {bright }}$ plasmablasts (early PCs) that have differentiated within the GC proper. Note that this section was stained only with the $9 \mathrm{G} 4 \mathrm{mAb}$ (and FITC-conjugated anti-rat) as secreted antibody captured in the follicular dendritic cell network are brightly stained by anti-IgM and 

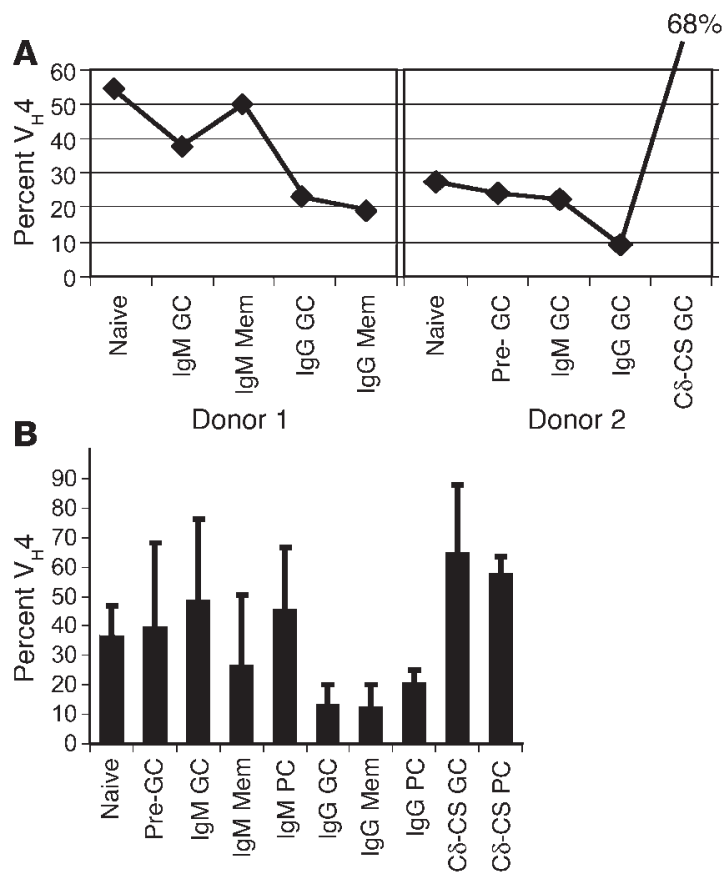

C

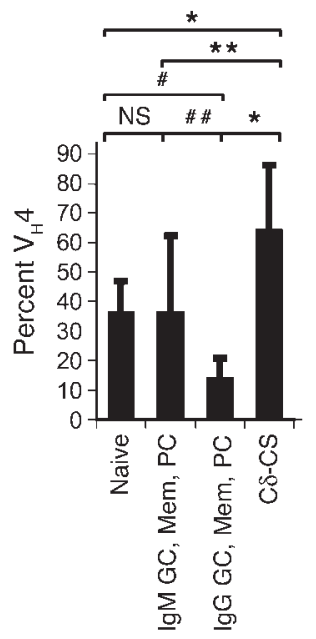

D
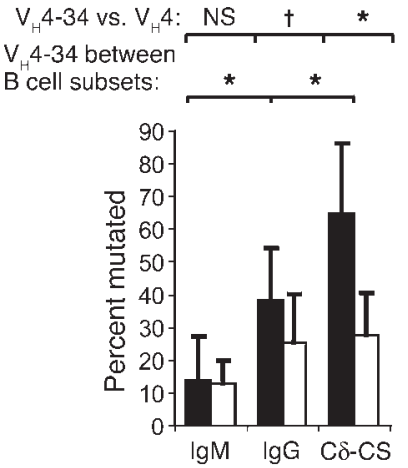

$V_{H}$ 4-34 gene segments Other $V_{\mathrm{H}} 4$ family segments

Figure 2

$\mathrm{V}_{\mathrm{H}} 4-34^{+} \mathrm{B}$ cell selection correlates with antibody isotype and is due to il antigen autoreactivity. $\mathrm{V}_{\mathrm{H}} 4$ family genes were randomly cloned and sequenced from various $B$ cell subpopulations sorted by flow cytometry. B cell subpopulation phenotypes are in the text, and Table 1 lists populations isolated from each donor and number of $\mathrm{V}$ genes sequenced per population. (A) $V_{H} 4-34$ usage in the various subpopulations of two donors. Similar analyses of all 29 donors are presented in Supplemental Figure 1. (B) Average use of $V_{H} 4-34$ by the various $B$ cell subpopulations between donors (means $\pm \mathrm{SD}$; Table 2 lists mean use of the remaining $\mathrm{V}_{\mathrm{H}} 4$ genes). $\mathrm{V}_{\mathrm{H}} 4-34$ encodes antibodies from the various IgM populations significantly more than the IgG populations (Student's $t$ test, $P<0.05$ ) and was used in the $\mathrm{C} \delta$-CS populations more than all others $(P<0.01)$. $(\mathbf{C}) \mathrm{V}_{\mathrm{H}} 4-34$ usage organized by Ig class. Student's $t$ test probabilities are indicated. ${ }^{*} P<0.0001$; ${ }^{* *} P=0.004 ;{ }^{\#} P=0.002$; \#\# $P=0.0008$. (D) $V_{\mathrm{H}} 4-34$ is probably selected due to its autoreactivity to il glycans. Bars indicate mean \pm SD of $V$ genes with mutations at amino acid positions 7, 23, 24, or 25. These amino acids are used for il glycan binding by $\mathrm{V}_{\mathrm{H}} 4-34^{+}$antibodies (W7 and AVY23-25). Despite equivalent mutation frequencies between $\mathrm{V}_{\mathrm{H}} 4-34^{+}$and other $\mathrm{V}_{\mathrm{H}} 4$ genes (Table 3 ), mutations at these amino acid positions are significantly selected only for $\mathrm{V}_{\mathrm{H}} 4-34$ genes, and only in association with CSR $\left(\chi^{2}\right.$ probabilities are indicated). ${ }^{\dagger} P<0.05$.

anti-IgG, masking the GC cells that express only low levels of surface Ig (Figure 1C). Upon assigning scores for 9G4 staining, we found that $7 \% \pm 1 \%$ (average $\pm \mathrm{SD}$ ) of the follicular mantle B cells from four donors are "encoded" by the $\mathrm{V}_{\mathrm{H}} 4-34$ gene segment. Analysis by PCR determined that $\mathrm{V}_{\mathrm{H}} 4$ encodes $37 \%$ of $\mathrm{V}_{\mathrm{H}} 4$ transcripts sequenced (Figure 2). Because $\mathrm{V}_{\mathrm{H}} 4$ genes represent approximately $20 \%$ of the total naive pool, based on the genetic frequency of $\mathrm{V}_{\mathrm{H}} 4$ genes (38), our own analyses (Methods), and those of others $(14,27,39)$, this $36 \%$ represents $7.4 \%$ of all $V_{H}$ genes $(0.2$ multiplied by $36 \%$ ), corresponding excellently to the immunohistochemical analysis. The sequencing data also corresponds well with the cytometric analysis presented in Figure 1A, where 9G4+ cells averaged $6 \% \pm 2 \%$ of the total from 24 donor samples. Previous analyses have demonstrated that analysis of $\mathrm{V}$ gene repertoires by bulk PCR and random sequencing is similarly quantitative to single-cell PCR (40). However, with the unique conditions of PCR primers used herein, we felt it necessary to verify the bulk PCR data by single-cell PCR. C $\delta$-CS B cells from two donors were bulk sorted, and then a portion of these cells was distributed as single cells into a 96-well PCR plate by the flow cytometer for single-cell RT-PCR. We found that as long as the single-cell PCR efficiency approached $90 \%$, the bulk-versus-single-cell analysis of $\mathrm{V}_{\mathrm{H}} 4$ and $\mathrm{J}_{\mathrm{H}}$ gene use corresponded excellently for all genes $\left(\mathrm{V}_{\mathrm{H}} 4-34, \mathrm{~J}_{\mathrm{H}} 4\right.$, and $\mathrm{J}_{\mathrm{H}} 6$ correspondence is presented in Table 4).
It is notable that bulk PCR analysis amplifying only $\mathrm{V}_{\mathrm{H}} 4$ genes does not provide correspondence of gene expression relative to other $V_{\mathrm{H}}$ gene families unless it is known what proportion of the total cells use $V_{\mathrm{H}} 4$ gene segments. For example, $20 \%$ of all naive cells use $V_{H} 4$ gene segments; thus reference to $50 \%$ of the naive cells expressing $\mathrm{V}_{\mathrm{H}} 4$-encoded antibodies would represent $10 \%$ of all naive cells. However, relative abundance of $\mathrm{V}_{\mathrm{H}} 4$ genes was not previously known for the $C \delta$-CS lineage. As indicated in Table 4, single-cell analysis of two donors indicates that $46 \%$ and $54 \%$ of total $\mathrm{B}$ cells use $\mathrm{V}_{\mathrm{H}} 4$ family Ig genes, and $\mathrm{V}_{\mathrm{H}} 4-34$ accounts for $30 \%$ and $42 \%$ of all C $\delta$-CS B cells, respectively, in these donors. Thus, $V_{H} 4-34$ is even more over-represented in the C $\delta$-CS lineage than as determined by the analyses in Figure 2. As indicated in Table 3 and previously (9), the C $\delta$-CS lineage B cells harbor more somatic mutations than any other B cell lineage, and thus this analysis further demonstrates the sensitivity of the $9 \mathrm{G} 4 \mathrm{mAb}$ to incorporated mutations, as analysis with 9G4 appears to have detected only approximately $20 \%$ of the $\mathrm{V}_{\mathrm{H}} 4-34^{+} \mathrm{C} \delta$-CS B cells (Figure $1 \mathrm{~A}$ ).

Selection of $V_{H}$ 4-34-utilizing $B$ cells in association with class switch is dependent on their autospecificity to the iI antigen. Due to the well-characterized natural autoreactivity of the $V_{\mathrm{H}} 4-34$ gene to the iI glycan, it is predicted that loss of $\mathrm{V}_{\mathrm{H}} 4-34-\mathrm{utilizing} \mathrm{B}$ cell clones in the classswitched pools is due to negative selection to avoid autoreactivity in the secondary Ig repertoire. Alternatively, B cells expressing Ig 


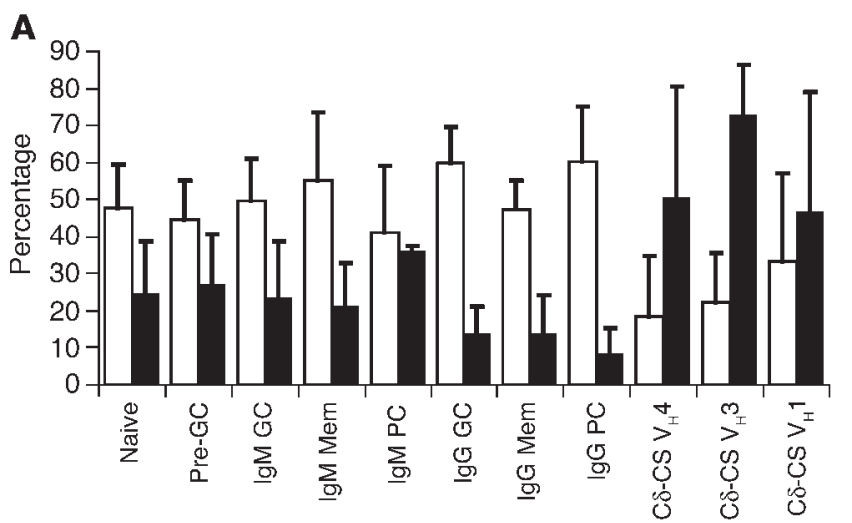

B
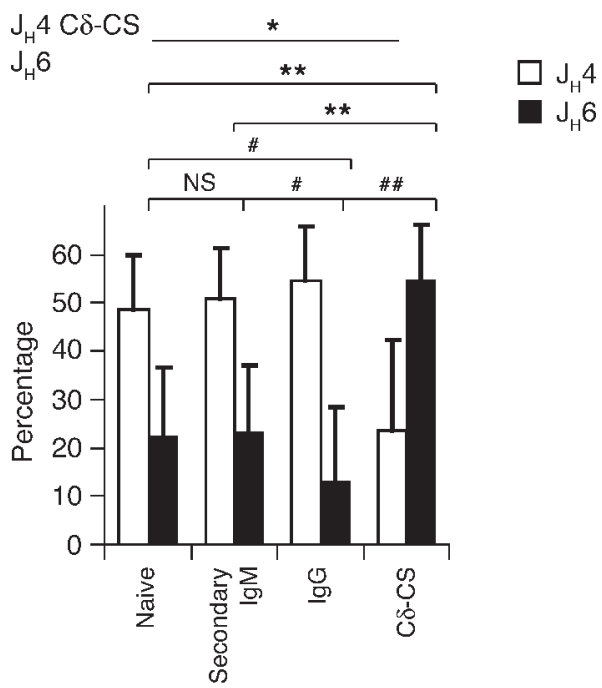

encoded by $\mathrm{V}_{\mathrm{H}}$ 4-34 may simply not be positively selected to participate in IgG-mediated immune responses. In order to address this issue, we considered the specific binding of $\mathrm{V}_{\mathrm{H}} 4-34$-encoded antibodies to the iI autoantigen. If indeed $\mathrm{B}$ cells utilizing $\mathrm{V}_{\mathrm{H}} 4-34$ are negatively selected, it can be predicted that $\mathrm{V}_{\mathrm{H}} 4-34^{+} \mathrm{B}$ cells surviving to selected populations, and particularly the IgG populations in which $V_{\mathrm{H}} 4-34$ counterselection is so apparent, might do so because the well-defined amino acids involved in iI glycan binding were somatically mutated during GC reactions. In Figure $2 \mathrm{D}, \mathrm{V}_{\mathrm{H}} 4-34^{+} \mathrm{V}$ genes from the various isotype pools are analyzed for loss of the iI antigen binding site due to accumulated somatic mutations. iI antigen specificity is generally independent of the CDR3 or the Ig light chain. Similar to the epitope of mAb 9G4 on $\mathrm{V}_{\mathrm{H}} 4-34$-encoded antibodies, the specific amino acids important for binding of $\mathrm{V}_{\mathrm{H}} 4-34$ to iI antigen are known through mutagenesis studies to be $\mathrm{W}$ at position 7 and AVY at positions 23-25 $(41,42)$. $V$ genes using $\mathrm{V}_{\mathrm{H}} 4-34^{+}$ segments from $\mathrm{IgG}^{+}$and $\mathrm{C} \delta$-CS B cells have accumulated somatic mutations causing replacement of amino acid positions 7 and 23-25 at a significantly higher frequency than did $\mathrm{V}$ genes encoded by other $\mathrm{V}_{\mathrm{H}} 4$ family gene segments (for $\mathrm{C} \delta$-CS cells, $67 \% \pm 18 \%$ of $\mathrm{V}_{\mathrm{H}} 4-34^{+}$vs. $28 \% \pm 16 \%$ of other $\mathrm{V}_{\mathrm{H}} 4, \chi^{2}, P<0.0001$; and for $\mathrm{IgG}^{+}$cells, $39 \% \pm 12 \%$ vs. $26 \% \pm 8 \%, \chi^{2}, P<0.05$; Figure $\left.2 \mathrm{D}\right)$. These mutations are not due to an overall greater frequency of mutations to $V_{H} 4-34$ gene segments which are mutated at a frequency similar to that of $\mathrm{V}$ genes using other $\mathrm{V}_{\mathrm{H}} 4$ family gene segments (Table 3 ). However, selection of iI binding site mutations is not evident for somatically

\section{Figure 3}

The autoimmune-associated $J_{H} 6$ gene is counterselected from IgG populations and selected into the C $\delta$-CS lineage. (A and $\mathbf{B}$ ) The $\mathrm{J}_{\mathrm{H}} 4$ gene segment is normally the dominant $J_{H}$ gene used in human $V_{H}$ gene rearrangements. The $\mathrm{J}_{H} 6$ gene is upregulated in receptor-edited and autoimmune B cells, linking it to autoimmune repertoires. Only usage of $J_{H} 4$ versus $J_{H} 6$ gene segments is shown and compared, as all other $J_{H}$ gene segment use is unchanged (other $J_{H}$ representations are in Table 2). $J_{H}$ analysis was based on naive $B$ cells (ten donors), $\operatorname{lgM} / \mathrm{D}^{+}$ pre-GC cells (three donors), IgM+ GC cells (eight donors), IgM+ memory cells (ten donors), IgM+ $\mathrm{PCs}$ (two donors), IgG+ $\mathrm{GC}$ cells (seven donors), IgG ${ }^{+}$memory cells (eight donors), $\lg G^{+} P C s$ (two donors), $\mathrm{C} \delta$-CS PCs (one donor), and C $\delta$-CS GC cells (ten, five, and four donors for $V_{H} 4, V_{H} 1$, and $V_{H} 3$ libraries, respectively). Bars indicate means of all donors and error bars, the SD. Student's $t$ test $P$ values are indicated. ${ }^{\star} P<0.0005$ vs. all; ${ }^{\star \star} P<0005$; ${ }^{\#} P<0.01 ;{ }^{\# \#} P<0.0001$.

mutated secondary $\operatorname{IgM}$ populations $\left(14 \% \pm 8 \%\right.$ of $\mathrm{V}_{\mathrm{H}} 4-34$ and $13 \%$ $\pm 9 \%$ of other $V_{H} 4$; analysis only of $\operatorname{IgM}^{+}$clones with $>1$ mutation). Thus, there appears to be a profound selection against $V_{H} 4-34-u t i-$ lizing B cells due to iI glycan binding, but in class-switched populations only $\left(\chi^{2}, P<0.0001\right.$ for C $\delta$-CS vs. IgG or secondary IgM, and also $\chi^{2}, P<0.0001$ for IgG vs. secondary $\left.\operatorname{IgM}\right)$. It is interesting to note that despite the unexpected selection of $\mathrm{V}_{\mathrm{H}} 4-34$-utilizing $\mathrm{B}$ cells into the C $\delta$-CS lineage (Figures $1 \mathrm{~A}$ and 2, A and B), the cells must still be tolerized against iI glycan binding to survive. In addition, the six recombinant $\mathrm{V}_{\mathrm{H}} 4$-34-encoded antibodies from classswitched populations expressed for the analysis of Figure $1 \mathrm{~B}$ were tested for their ability to agglutinate erythrocytes at low temperatures (cold agglutination). Cold agglutination is a hallmark of $\mathrm{V}_{\mathrm{H}} 4-34$ gene-encoded antibodies and is indicative of their ability to bind the iI antigen $(42,43)$. Although three of these antibodies had mutations not directly at amino acid positions 7 and 23-25, only one of the six was able to agglutinate red blood cells in the cold at a low level, but not at a level comparable to that of control sera from a patient with cold agglutinin disease or the FS7 control antibody (data not shown). In conclusion, the selection for specific mutations of amino acids at the iI antigen binding site of $\mathrm{V}_{\mathrm{H}} 4-34$ genes but not other $\mathrm{V}_{\mathrm{H}} 4$ genes is highly suggestive that $\mathrm{B}$ cells using $\mathrm{V}_{\mathrm{H}} 4-34$ are being counterselected due to their iI antigen autoreactivity.

As described in the previous section, consistent with this analysis of iI epitope mutations, mAb $9 \mathrm{G} 4$ only detects $20 \%$ of the C $\delta$-CS B cells and half of the already greatly reduced "IgG-encoded" B cell clones. However, based on the low frequency (14\%) of iI glycanbinding mutations and thus the 9G4 epitope of mutated IgM clones, we would have expected higher detection of IgM clones by the $9 \mathrm{G} 4 \mathrm{mAb}$. Because $\mathrm{V}_{\mathrm{H}} 4-34$ is found at a similar frequency in IgM cells and naive cells, we would have predicted 9G4 binding to equal the frequency of naive cell detection by $9 \mathrm{G} 4$ multiplied by the frequency of clones retaining the 9G4 epitopes in the IgM GC and memory cells, or $6 \% \times 0.86=5 \%$. However, only $3 \%$ of IgM memory cells were actually detected (Figure $1 \mathrm{~A}$ ). Though seemingly minor, this $2 \%$ discrepancy is significant because binding of $9 \mathrm{G} 4 \mathrm{mAb}$ to IgM clones in Figure 1A is significantly different from that of naive clones by Student's $t$ test $(P<0.01)$. Figure $1 \mathrm{~A}$ is an analysis of $\mathrm{CD} 27^{+}$IgM memory cells from blood. The autoantigen bound by $\mathrm{V}_{\mathrm{H}} 4-34$ is the iI glycan that is found in abundance on erythrocytes. Both iI antigen binding and the 9G4 epitope found in the FW1 region are affected in some $\mathrm{V}_{\mathrm{H}} 4$-34-encoded antibodies by the CDR3 and light chain sequences $(37,42)$, possibly explaining the discrepancy between the current sequencing analysis and the cyto- 
Table 2

$\mathrm{V}_{\mathrm{H}} 4$ and $\mathrm{J}_{\mathrm{H}}$ gene segment utilization

\begin{tabular}{|c|c|c|c|c|c|c|c|c|c|c|}
\hline & $V_{H} 4-04^{A}$ & $V_{H} 4-28^{A}$ & $V_{H} 4-30-2^{A}$ & $V_{H} 4-30-4^{A}$ & $V_{H} 4-31^{A}$ & $V_{H} 4-34^{A}$ & $V_{H} 4-39^{A}$ & $V_{H} 4-59^{A}$ & $V_{H} 4-61^{A}$ & $V_{H} 4-b^{A}$ \\
\hline Naive & $8 \pm 7 \%$ & $0 \pm 0 \%$ & $0 \pm 1 \%$ & $5 \pm 8 \%$ & $11 \pm 9 \%$ & $37 \pm 10 \%$ & $12 \pm 6 \%$ & $18 \pm 11 \%$ & $10 \pm 11 \%$ & $0 \pm 0 \%$ \\
\hline Pre-GC & $3 \pm 4 \%$ & $0 \pm 0 \%$ & $2 \pm 3 \%$ & $7 \pm 2 \%$ & $19 \pm 13 \%$ & $40 \pm 29 \%$ & $10 \pm 4 \%$ & $16 \pm 14 \%$ & $2 \pm 2 \%$ & $1 \pm 3 \%$ \\
\hline $\operatorname{IgM} G C$ & $5 \pm 8 \%$ & $1 \pm 3 \%$ & $1 \pm 3 \%$ & $4 \pm 4 \%$ & $18 \pm 15 \%$ & $43 \pm 26 \%$ & $12 \pm 7 \%$ & $13 \pm 9 \%$ & $2 \pm 3 \%$ & $1 \pm 2 \%$ \\
\hline $\lg G \mathrm{GC}$ & $5 \pm 4 \%$ & $0 \pm 1 \%$ & $2 \pm 2 \%$ & $2 \pm 4 \%$ & $22 \pm 14 \%$ & $11 \pm 8 \%$ & $22 \pm 7 \%$ & $29 \pm 11 \%$ & $6 \pm 7 \%$ & $1 \pm 3 \%$ \\
\hline IgM memory & $3 \pm 5 \%$ & $1 \pm 1 \%$ & $1 \pm 2 \%$ & $3 \pm 6 \%$ & $8 \pm 7 \%$ & $28 \pm 24 \%$ & $19 \pm 15 \%$ & $21 \pm 14 \%$ & $15 \pm 10 \%$ & $1 \pm 2 \%$ \\
\hline IgG memory & $4 \pm 5 \%$ & $0 \pm 0 \%$ & $3 \pm 5 \%$ & $8 \pm 12 \%$ & $16 \pm 12 \%$ & $12 \pm 8 \%$ & $23 \pm 11 \%$ & $26 \pm 14 \%$ & $6 \pm 8 \%$ & $1 \pm 2 \%$ \\
\hline IgM PC & $9 \pm 7 \%$ & $0 \pm 0 \%$ & $0 \pm 0 \%$ & $4 \pm 5 \%$ & $0 \pm 0 \%$ & $46 \pm 21 \%$ & $1 \pm 2 \%$ & $11 \pm 4 \%$ & $30 \pm 39 \%$ & $0 \pm 0 \%$ \\
\hline $\lg G P C$ & $13 \pm 2 \%$ & $1 \pm 1 \%$ & $1 \pm 1 \%$ & $9 \pm 12 \%$ & $14 \pm 20 \%$ & $20 \pm 5 \%$ & $19 \pm 3 \%$ & $21 \pm 1 \%$ & $3 \pm 2 \%$ & $0 \pm 0 \%$ \\
\hline C $\delta-C S G C$ & $0 \pm 1 \%$ & $0 \pm 0 \%$ & $2 \pm 4 \%$ & $4 \pm 8 \%$ & $10 \pm 8 \%$ & $65 \pm 23 \%$ & $4 \pm 8 \%$ & $7 \pm 9 \%$ & $4 \pm 8 \%$ & $3 \pm 3 \%$ \\
\hline \multirow[t]{2}{*}{ C $\delta$-CS PC } & $1 \%$ & $0 \%$ & $18 \%$ & $19 \%$ & $0 \%$ & $58 \%$ & $0 \%$ & $4 \%$ & $1 \%$ & $0 \%$ \\
\hline & $J_{H}-1^{A}$ & $\mathrm{~J}_{\mathrm{H}}-2^{\mathrm{A}}$ & $J_{H}-3^{A}$ & $J_{H^{-}}-4^{A}$ & $J_{H}-5^{A}$ & $J_{H}-6^{A}$ & & & & \\
\hline Naive & $3 \pm 4 \%$ & $3 \pm 3 \%$ & $10 \pm 7 \%$ & $48 \pm 12 \%$ & $12 \pm 8 \%$ & $25 \pm 14 \%$ & & & & \\
\hline Pre-GC & $1 \pm 1 \%$ & $4 \pm 6 \%$ & $10 \pm 4 \%$ & $45 \pm 11 \%$ & $13 \pm 6 \%$ & $27 \pm 14 \%$ & & & & \\
\hline $\operatorname{IgM} G C$ & $1 \pm 2 \%$ & $3 \pm 3 \%$ & $10 \pm 7 \%$ & $50 \pm 11 \%$ & $12 \pm 6 \%$ & $24 \pm 15 \%$ & & & & \\
\hline $\operatorname{lgG} G C$ & $2 \pm 2 \%$ & $3 \pm 2 \%$ & $10 \pm 6 \%$ & $60 \pm 10 \%$ & $13 \pm 5 \%$ & $14 \pm 7 \%$ & & & & \\
\hline IgM memory & $3 \pm 3 \%$ & $4 \pm 4 \%$ & $6 \pm 6 \%$ & $54 \pm 19 \%$ & $15 \pm 6 \%$ & $19 \pm 12 \%$ & & & & \\
\hline IgG memory & $3 \pm 5 \%$ & $5 \pm 6 \%$ & $11 \pm 5 \%$ & $47 \pm 8 \%$ & $20 \pm 11 \%$ & $14 \pm 11 \%$ & & & & \\
\hline $\operatorname{lgM} P C$ & $0 \pm 0 \%$ & $0 \pm 0 \%$ & $7 \pm 4 \%$ & $41 \pm 18 \%$ & $16 \pm 12 \%$ & $36 \pm 2 \%$ & & & & \\
\hline $\lg G P C$ & $2 \pm 1 \%$ & $5 \pm 5 \%$ & $6 \pm 2 \%$ & $60 \pm 15 \%$ & $19 \pm 9 \%$ & $8 \pm 7 \%$ & & & & \\
\hline C $\delta$-CSB & $1 \pm 2 \%$ & $3 \pm 6 \%$ & $13 \pm 22 \%$ & $23 \pm 18 \%$ & $9 \pm 11 \%$ & $52 \pm 29 \%$ & & & & \\
\hline
\end{tabular}

AValues represent the mean percent utilization of each gene for the various donors \pm the standard deviation. ${ }^{\mathrm{B}}$ Combined total mean $\mathrm{J}_{\mathrm{H}}$ usage of $\mathrm{V}_{\mathrm{H}} 1$, $\mathrm{V}_{\mathrm{H}} 3$, and $\mathrm{V}_{\mathrm{H}} 4$ rearrangements.

metric analysis of this and a previous report from a different group (14). Thus, although the repertoire representation of $V_{\mathrm{H}} 4-34-u t i-$ lizing B cells in the secondary IgM pools may not be significantly reduced, there could be selection of $\operatorname{IgM}^{+} V_{\mathrm{H}} 4-34^{+} \mathrm{B}$ cell clones with light chains or CDR3 regions that effectively "edit" the ability to bind iI glycan, which would also affect the 9G4 epitope involving the same region and amino acids of $\mathrm{V}_{\mathrm{H}} 4-34$-encoded $\mathrm{Ig}$ molecules. Similarly, there may be selection of $\operatorname{IgM}^{+} \mathrm{V}_{\mathrm{H}} 4-34^{+} \mathrm{B}$ cell clones with somatic mutations of the more-mutable CDR-encoded amino acids also indirectly affecting iI-glycan binding and also with the ancillary effect on detection by $9 \mathrm{G} 4$. A search for other possible mutated sites in the IgM clones that could account for this discrepancy was fruitless. In conclusion, (a) there is selection against $V_{H} 4-34-$ utilizing $\mathrm{B}$ cells that retain il glycan binding from all populations of B cells, including $\mathrm{C} \delta$-CS cells, despite profound selection of $\mathrm{V}_{\mathrm{H}}$ 4-34-utilizing $\mathrm{B}$ cells toward this differentiation; and (b) although not significant at the gross level of repertoire analysis or sequence analysis for iI binding mutations, IgM memory cells may still be selected to avoid this autoreactivity. In the following sections, a number of other features of the human $V$ gene repertoire associated with autoreactivity or autoimmunity are characterized to generalize the findings for $\mathrm{V}_{\mathrm{H}} 4-34$ gene usage to the total Ig repertoire.

Peripheral selection of the autoimmune-associated $J_{H} 6$ gene is also associated with class switch. $\mathrm{J}_{\mathrm{H}} 6$ predominance has been detected in a population of receptor-editing human B cells (44-46) and is counterselected from the pre-B cell repertoire upon progression to naive mature B cells (27), and thus it is already known to be subjected to primary B cell-selective mechanisms. Increased $\mathrm{J}_{\mathrm{H}} 6$ usage has also been associated with autoreactive lymphocytic leukemia (47) and Sjogren syndrome (48). Finally, direct antibody expression analyses have recently demonstrated that $\mathrm{J}_{\mathrm{H}} 6$-encoded antibodies are more likely to "encode" antinuclear antigen (ANA) autoreactivity and polyreactivity $(27,46)$. As indicated in Figure 3 , the $\mathrm{J}_{\mathrm{H}} 6$ seg- ment encodes about one-quarter of the Ig molecules of the naive and secondary $\operatorname{IgM}$ populations (naive $=25 \% \pm 14 \%$; $\operatorname{IgM} / \mathrm{D}^{+}$pre$\mathrm{GC}=27 \% \pm 14 \% ; \operatorname{IgM}^{+} \mathrm{GC}=24 \% \pm 15 \% ; \operatorname{IgM}^{+}$memory $=21 \% \pm 12 \%$; and $\operatorname{IgM}^{+} \mathrm{PC}=36 \% \pm 2 \%$; these populations were statistically similar), but use of $\mathrm{J}_{\mathrm{H}} 6$ is stringently counterselected from all IgG populations $\left(\mathrm{IgG}^{+} \mathrm{GC}=14 \% \pm 7 \%, \mathrm{IgG}^{+}\right.$memory $=14 \% \pm 11 \%$, and $\mathrm{IgG}^{+}$ $\mathrm{PC}=8 \% \pm 7 \%$; these populations are all similar, but each is statistically different from naive and the various IgM populations by Student's $t$ tests at a level of $P<0.05$ ). In addition, similar to $\mathrm{V}_{\mathrm{H}} 4-34$ usage, cells utilizing $\mathrm{J}_{\mathrm{H}} 6$ appear to preferentially class switch to $\mathrm{C} \delta$, where $50 \% \pm 30 \%$ of the cells have $\mathrm{V}$ genes encoded by $\mathrm{J}_{\mathrm{H}} 6(P<0.001$ versus all other populations), with a significant reduction in the use of the normally dominant $\mathrm{J}_{\mathrm{H}} 4$ gene segment $(P<0.001)$. Populations analyzed for the various donors are indicated in Table 1. Reorganization of $\mathrm{J}_{\mathrm{H}}$ gene segment usage by Ig class in Figure $3 \mathrm{~B}$ more pointedly demonstrates the class-related selection of the $\mathrm{J}_{\mathrm{H}}$ gene repertoire. Compared with $V$ genes from naive cells $(22 \% \pm 14 \%$ $\mathrm{J}_{\mathrm{H}} 6 ; 11$ donors) and $\mathrm{V}$ genes from differentiated secondary $\operatorname{IgM} \mathrm{B}$ cells $\left(23 \% \pm 13 \% \mathrm{~J}_{\mathrm{H}} 6 ; 20\right.$ donors $)$, B cells with $\mathrm{J}_{\mathrm{H}} 6$-utilizing $\mathrm{V}$ genes are significantly counterselected from the IgG populations $(13 \% \pm 9 \%$; 18 donors; $P<0.01$ by paired Student's $t$ tests). B cells utilizing the normally dominant $\mathrm{J}_{\mathrm{H}} 4$ gene are significantly selected into the IgG

\section{Table 3}

Mean mutations in various isotype pools

\begin{tabular}{lccc}
\hline & $\mathbf{V}_{\mathbf{H}^{\mathbf{A}}}$ & $\mathbf{V}_{\mathbf{H}} \mathbf{4 - 3 4 ^ { \mathbf { B } }}$ & Sequences \\
IgM GC, memory, PC & 5 & 5 & 512 \\
IgG GC, memory, PC & 14 & 14 & 419 \\
C -CS lineage & 23 & 24 & 265
\end{tabular}

AMean mutations per sequence for all $\mathrm{V}_{\mathrm{H}}$ rearrangements. ${ }^{B}$ Mean mutations per sequence for $\mathrm{V}_{\mathrm{H}} 4-34$ rearrangements. 
A
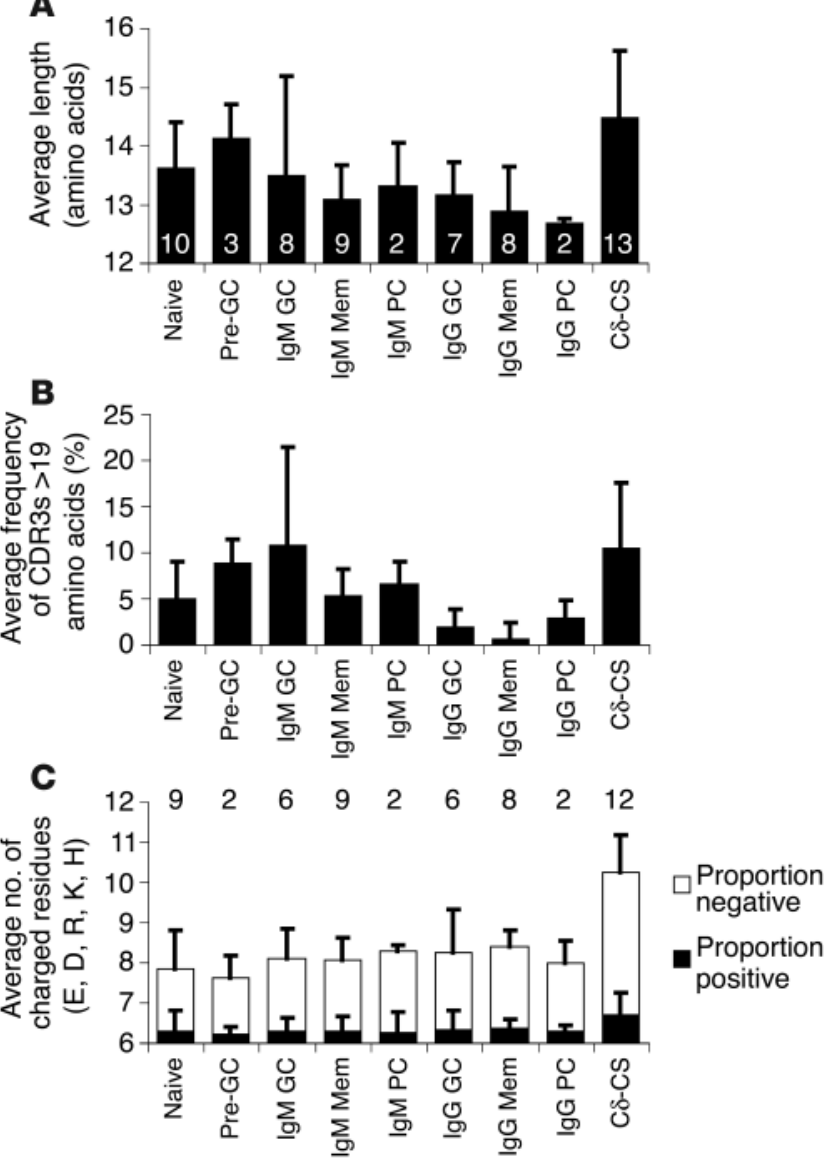

lineages $(P=0.04)$. Finally, $\mathrm{J}_{\mathrm{H}} 6$ is highly over-represented in the C $\delta$-CS lineage in $50 \pm 18 \%$ of the $\mathrm{V}_{\mathrm{H}} \mathrm{DJ}_{\mathrm{H}}$ transcripts (17 donors, $P<0.0005$ for $\mathrm{C} \delta$-CS vs. naive cells and secondary $\mathrm{IgM}^{+} \mathrm{B}$ cells; and $P<0.0001$ vs. IgG ${ }^{+} \mathrm{B}$ cells). Use of the remaining $\mathrm{J}_{\mathrm{H}}$ genes is listed in Table 2. Selection of the $\mathrm{J}_{\mathrm{H}} 6$ gene segment into the $\mathrm{C} \delta$-CS lineage is also independent of the $V_{H}$ gene used, as similar results were obtained for $\mathrm{V}$ genes formed by rearrangements of $\mathrm{V}_{\mathrm{H}} 1$ family genes $(46 \% \pm 33 \%)$ and $V_{\mathrm{H}} 3$ family genes $(73 \% \pm 14 \%)$ (Figure 3$)$. In conclusion, $\mathrm{J}_{\mathrm{H}} 6$ gene usage is an independently selected feature indicative of an autoimmune antibody repertoire that is selected in the periphery solely associated with class switch.

Long CDR3s are a classic hallmark of an autoimmune repertoire that are also selected in mature B cells solely on the basis of Ig class. The correlation of long CDR3s to autoimmunity has been made both for humans (49) and in mouse models of lupus, such as $\mathrm{mrl} / \mathrm{lpr}$ mice $(50,51)$. Longer CDR3s have also been demonstrated in receptor-editing human $B$ cells (44-46) and are counterselected during normal human B cell development (27). Finally, direct antibody expression analyses have recently demonstrated that antibodies with long CDR3s are more likely to have ANA autoreactivity and polyreactivity $(27,46)$. Typically, a population is judged as having longer CDR3 regions if a higher frequency of $B$ cells are found with excessively long CDR3 regions. Average CDR3 lengths are of limited utility because most $V$ genes predominantly have CDR3 lengths between 13 and 14 amino acids with some proportion of outliers. If there is counterselection of these outliers, then there will still be little effect on the mean. However, as indicated in Figure 4A, $V$ genes from B cells of the C $\delta$-CS lineage average

\section{Figure 4}

Analysis of CDR3 length and frequency of charged residues in various $V$ gene libraries. $V$ genes with long CDR3s and increased numbers of charged amino acids have been associated with increased autoreactivity and are typical in the repertoires of people and mice with autoimmune disease. The $n$ values of donors analyzed per population are indicated on and above the bars, and the particular donors compared are in Table 1. (A) Average length of CDR3s in amino acids of the various donors for the various populations. The average lengths of the $C \delta$-CS and pre-GC populations are significantly greater then all IgG populations and the IgM memory population ( $t$ test, $P<0.01$ ), although the pre-GC cells were from only three donors, one of whom had a particularly large average CDR3 length. (B) Average frequency of $\mathrm{V}$ gene clones between donors that are more than 19 amino acids in length. The $\mathrm{C} \delta$-CS frequency of clones with CDR3s longer than 19 amino acids is similar to that of the naive and IgM populations. The IgG populations have on average significantly fewer clones with lengths greater than 19 amino acids than do the naive, IgM, and C $\delta$-CS populations ( $t$ test, $P<0.05$ ). (C) The mean number of charged residues in the CDR regions averaged among donors for each population where positively charged residues $(\mathrm{R}, \mathrm{K}, \mathrm{H})$ are the black portion of the bars, and negatively charged (acidic) residues $(E$ and $D)$ are represented by the white portion of the bars. Error bars indicate standard deviations between the various donors for all panels.

the longest CDR3s, although only significantly greater than the average lengths of CDR3s of $V$ genes from IgG (Student's $t$ test, $P<0.01$ ) and the IgM memory (Student's $t$ test, $P<0.01$ ) populations. In regards to difference in mean CDR3 length between IgM and $\operatorname{IgG}$ populations, although longer CDR3s are generally found in the $\mathrm{V}$ genes of $\operatorname{IgM}$ populations, only the means of naive and the $\operatorname{IgM} \mathrm{D}^{+}$ pre-GC populations were significantly increased over the IgG memory and IgG PC populations (not the IgG GC). However, when the mean numbers of clones between the various donors with excessively long CDR3 regions (>19 residues) were considered, the naive, all IgM populations (including IgM pre-GC, GC, memory, and PC), and the $\mathrm{C} \delta$-CS lineage were statistically similar, and all had significantly more clones with CDR 3 lengths greater than 19 amino acids than any of the IgG GC, memory, or PC populations at a level of $P<0.05$ by Student's $t$ test. It is interesting to note the immense variation between the eight donors from which IgM GC populations were analyzed for both average CDR3 lengths and regarding the number of clones with CDR3s longer than 19 amino acids (see Figure 4, A and $\mathrm{B}$, error bars representing $\mathrm{SD}$ ), suggesting a significant effect of anti-

\section{Table 4}

Single-cell RT-PCR (scRT-PCR) and bulk PCR analysis of $C \delta$-Cs cells

\begin{tabular}{lcccccc}
\hline & $\mathbf{V}_{\mathbf{H}} \mathbf{4}^{\mathrm{A}}$ & \multicolumn{2}{c}{$\mathbf{V}_{\mathbf{H}} \mathbf{4 - 3 4 ^ { \mathbf { B } }}$} & \multicolumn{2}{c}{$\mathbf{J}_{\mathbf{H}}$} & Sequences \\
& & $\mathbf{V}_{\mathbf{H}} \mathbf{4}$ & Total & $\mathbf{J}_{\mathbf{H}} \mathbf{4}$ & $\mathbf{J}_{\mathbf{H}} \mathbf{6}$ & $\mathbf{V}_{\mathbf{H}} / \mathbf{J}_{\mathbf{H}}$ \\
& & $66 \%$ & $30 \%$ & $18 \%$ & $75 \%$ & $76 / 35^{C}$ \\
Donor 19, scPCR: & $46 \%$ & $66 \%$ & & \\
Donor 19, bulk PCR: & & $69 \%$ & & $16 \%$ & $76 \%$ & 26 \\
Donor 18, scPCR: & $54 \%$ & $79 \%$ & $42 \%$ & $14 \%$ & $72 \%$ & 78 \\
Donor 18, bulk PCR: & & $81 \%$ & & $14 \%$ & $76 \%$ & 26 \\
& & & & & &
\end{tabular}

APercent of " $\mathrm{V}_{\mathrm{H}} 4$ family-encoded" cells from total cells. BPercent " $\mathrm{V}_{\mathrm{H}} 4$-34-encoded" rearrangements of $\mathrm{V}_{\mathrm{H}} 4$ genes and of total $\mathrm{B}$ cells. ${ }^{C} J_{H}$ analysis was considered for $V_{H} 4$ only for donor 1 because bulk analysis was only of $\mathrm{V}_{\mathrm{H}} 4$ genes and there is a $\mathrm{V}_{\mathrm{H}} 3$ clonal expansion utilizing JH6. For each donor, 84 cells were analyzed (efficiency: $90 \%$, donor $1 ; 93 \%$, donor 2 ). 
A
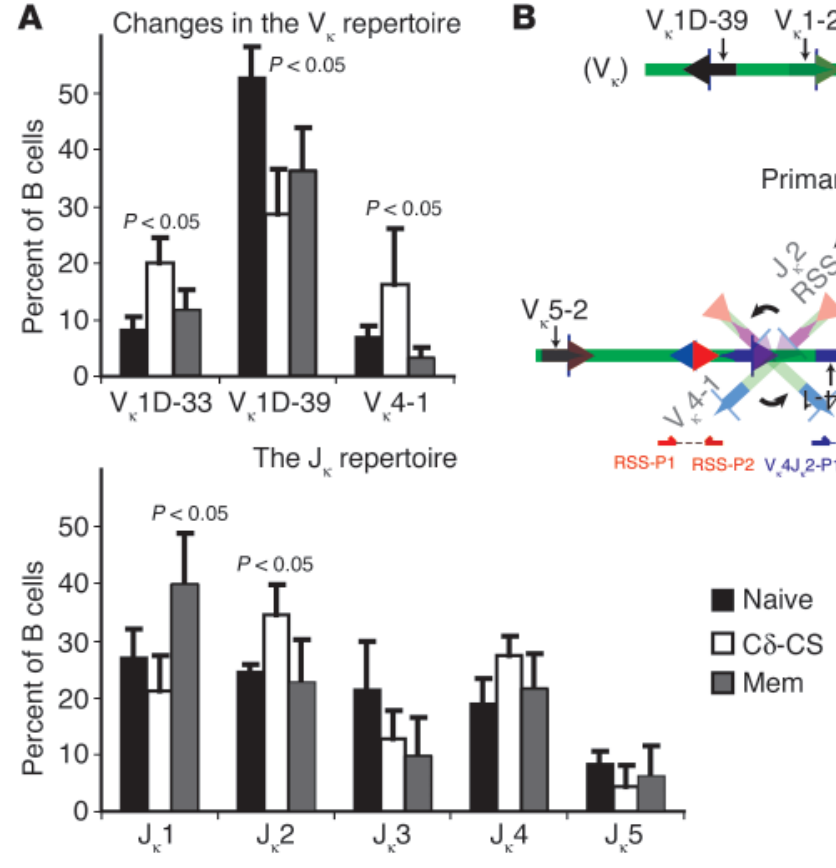

B

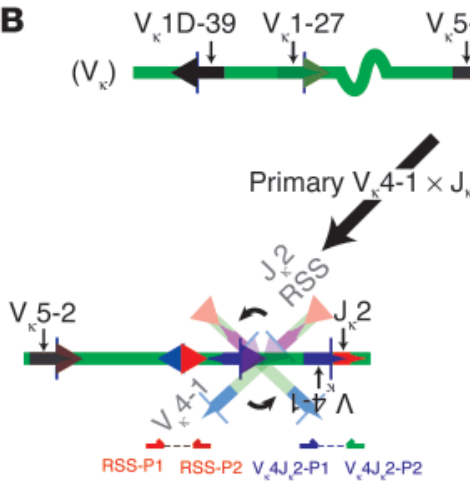

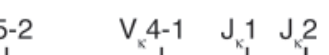

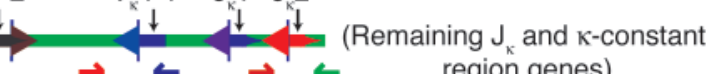

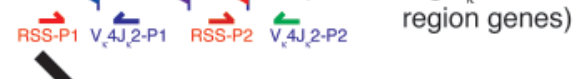
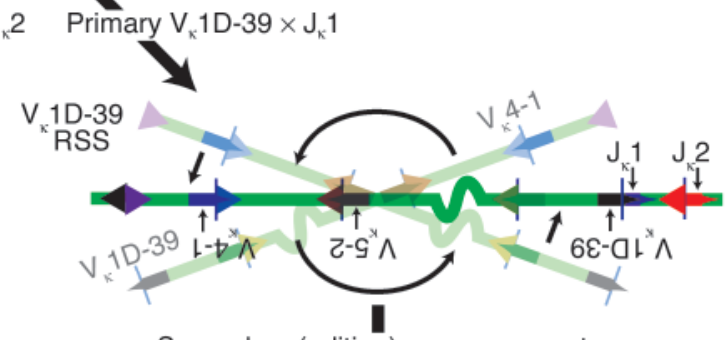

Secondary (editing) rearrangement
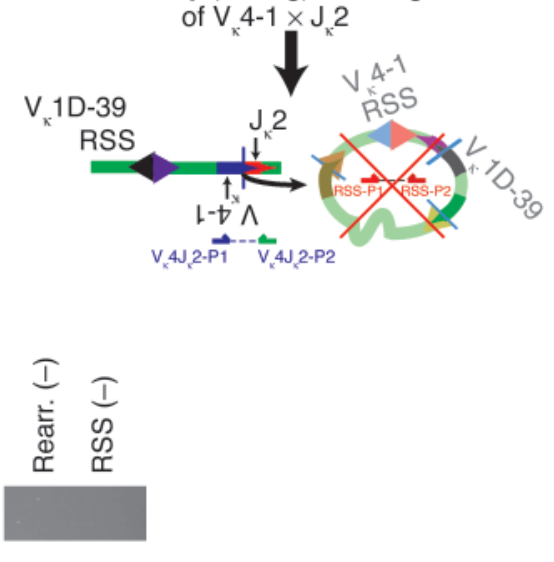

\section{Figure 5}

Analysis of the $\mathrm{VJ}_{\mathrm{K}}$ repertoire and configuration of the $\mathrm{V}_{\mathrm{K}}$ loci for evidence of receptor editing. (A) Mean $\pm S D$ of $V_{\kappa}$ and $J_{\kappa}$ gene segments used at significantly different frequencies between naive (four donors), $\mathrm{C} \delta$-CS (five donors), and combined total memory (two donors) plus IgG ${ }^{+}$memory (two donors). (B) Semi-quantitative PCR was used to determine if increased $V_{k} 4-1$ usage provides evidence of receptor editing for $C \delta$-CS cells. $V_{k} 4-1$ is the most $J_{k}$-proximal $V_{k}$ gene and is inverted. Thus, primary $V_{k} 4-1$ rearrangements retain the RSS junction (left), but following any other primary inversional rearrangement, a secondary (editing) $\mathrm{V}_{\mathrm{k}} 4-1$ rearrangement will delete the RSS junction (right). Thus, analysis of the genetic configuration of $V_{k} 4-1-$ to- $J_{k} 2$ rearrangements provides a measure of receptor editing for all $V_{k}$ genes. The relative proportion of primary versus editing rearrangements was determined by PCR using the primer sets indicated to get the ratio of $\bigvee_{\kappa} 4-1-$ to- $J_{k} 2$ rearrangements (primers: $\mathrm{V}_{\mathrm{k}} 4 \mathrm{~J}_{\mathrm{K}} 2-\mathrm{P} 1$, blue arrows; and $\mathrm{V}_{\mathrm{k}} 4 \mathrm{~J}_{\mathrm{K}} 2-\mathrm{P} 2$, green arrows) compared to RSS junctions (RSS-P1, red arrows; and RSS-P2, orange arrows). (C) Genomic DNA template from naive, $C \delta$-CS, and memory $B$ cells were normalized for $V_{k} 4-1-$ to- $J_{k} 2$ rearrangements (Rearr.); then the relative proportion of RSS junctions were determined by PCR at three dilutions of template (wedges). There was ten-fold less $V_{k} 4-1-$ to- $J_{\kappa} 2$ RSS junctions for the $\mathrm{C} \delta$-CS population, indicating that the increased $\mathrm{V}_{\mathrm{K}} 4-1$ rearrangements for this population are due to receptor editing. $(-)$, buffer controls.

gen selection on average CDR3 length. In summary, as with analyses of $\mathrm{V}_{\mathrm{H}} 4-34$ and $\mathrm{J}_{\mathrm{H}}$ gene usage, CDR3 length demonstrates another repertoire variation that is associated with autoreactive $\mathrm{B}$ cells and is counterselected from the IgG populations.

Additional distinctions analyzed for the various B cell subpopulations provided no further evidence of repertoire variation beyond that found in association with class switch. Separation of naive cells $\left(\mathrm{IgD}^{+} \operatorname{IgM}{ }^{+} \mathrm{CD} 38^{-}\right)$from two of the donors (donors 2 and 24) into CD23- and $\mathrm{CD} 23^{+}$subsets (or $\mathrm{Bm} 1$ and $\mathrm{Bm} 2$, as previously described) (3) found that these two naive $\mathrm{B}$ cell differentiations were the same for all analyses described above, and thus these groups were pooled. Similar differential analyses were performed comparing IgM versus $\operatorname{IgD} V$ gene libraries for the naive cells of one patient (donor 2, Bm1) and the pre-GC cells $\left(\mathrm{IgM}^{+} \operatorname{IgD} \mathrm{CD}^{+} 8^{+}\right)$of two patients (donors 2 and 11$)$. $\operatorname{IgM}$ versus $\operatorname{IgD}$ libraries were also equivalent and the data pooled for the various analyses when from a single donor and population. In addition, two of the donor GC cell populations (from donors 2 and 5) were separated with anti-CD77 into centroblast $\left(\mathrm{CD} 77^{+}\right)$and centrocyte
$\left(\mathrm{CD} 77^{-}\right)$pools and were found to be the same. Finally, inclusion of anti-CD27 (with anti-IgD and anti-CD38) for sorting cells of two tonsil specimens (donors 18 and 19) provided finer distinction of GC $\left(\mathrm{IgD}^{-} \mathrm{CD} 38^{-} \mathrm{CD} 27^{+}\right)$and memory cells $\left(\mathrm{IgD}^{-} \mathrm{CD} 38^{+} \mathrm{CD} 27^{-}\right)$but produced no significant differences from GC or memory populations analyzed from other donors. None of these finer distinctions produced differential $V$ gene repertoires other than the association with Ig class. It is also notable that PCs can arise via GC-independent differentiation; however, there is no way to sort $\operatorname{IgM}^{+}$PCs into GCdependent versus GC-independent fractions. However, because naive versus $\operatorname{IgM}^{+}$pre-GC, $\operatorname{IgM}^{+} \mathrm{GC}$, and subdivisions of $\operatorname{IgM}^{+} \mathrm{GC}$ cells (centroblasts versus centrocytes), or IgM+ memory cells from both blood and tonsil were all similar, we can predict that differentiation of $\mathrm{IgM}^{+} \mathrm{PCs}$ into GC-dependent or -independent fractions would not affect selection of $\mathrm{V}_{\mathrm{H}} 4-34, \mathrm{~J}_{\mathrm{H}}$, or CDR3 length.

$B$ cells selected into the $C \delta$-CS population have an increased number of charged residues in their CDRs. Charged residues in autoantibody hypervariable regions are a common feature associated with polyre- 
activity, ANA autoreactivity, and are particularly important in producing anti-DNA reactivity (52-54). Charged residues are increased in human immature and naive $B$ cells that are ANA reactive or are polyreactive $(27,46)$. In addition, increased numbers of charged residues are found among the Ig's of editing human B cells (44-46). Finally, antibodies with excessive charged residues are counterselected during progression from pre-B and immature to naive $\mathrm{B}$ cells (27). As indicated in Figure 4C, C $\delta$-CS lineage populations from the various donors averaged significantly more charged residues in the CDRs than did all other B cell populations studied ( $t$ test, $P<0.05$ or more significant for $\mathrm{C} \delta$-CS versus any other population). The C $\delta$-CS lineage populations averaged $25-30 \%$ more positively charged residues (Figure 4C, black portion of bars) associated with anti-DNA reactivity, including arginine, lysine, and histidine, and 15-20\% more acidic residues (Figure 4C, white portion of bars), including glutamic acid and aspartic acid. Unlike the comparisons of $\mathrm{V}_{\mathrm{H}} 4-34$ and $\mathrm{J}_{\mathrm{H}} 6$ gene segment usage or CDR3 length, the naive, various differentiated IgM, and various IgG populations all had a similar mean number of charged residues. The average number of charged residues was eight. It is notable that on average, around $35 \%$ of the clones of the naive populations and their most similar compartment, the pre-GC populations, had more than eight (average) charged residues. In comparison, approximately 45\% (43-51\%) of the clones of the various IgM or IgG GC, memory, and PC compartments had more than eight charged residues, although the variance between donors within each of these populations precluded statistical significance. Only the $C \delta$-CS lineage had significantly more than the others, averaging more than eight charged residues in $72 \%$ of the clones. However, this reduction of charged residues for naive and pre-GC cells and the remaining populations gives rise to the possibility that antigen encounter selects for $\mathrm{B}$ cells with charged residues in the antibody hypervariable region. Thus, the combination of selection of B cells that are autoreactive due to an excess of charged residues and simultaneous selection for antigenic reactivity may account for the particularly high frequency of charged residues in the $C \delta$-CS lineage. In conclusion, B cells with $\mathrm{V}_{\mathrm{H}}$ genes encoding increased numbers of charged residues in the CDRs preferentially undergo class switch to $C \delta$.

$C \delta$-CS B cells are selected from a population of B cells that has been subjected to extensive receptor editing. Receptor editing is the most clearly established selective mechanism that permanently alters an autoreactive $\mathrm{B}$ cell, and therefore it can be assayed experimentally. The $\mathrm{C} \delta$-CS lineage uses more than $90 \% \lambda$ light chains, in contrast to the normally expected $30-40 \% \lambda$ usage $(7,9)$. Light chain rearrangement is an ordered process $\left(V_{\kappa}\right.$, then $V \lambda$ [ref. 55]), and increased $\lambda$ usage has been associated with receptor editing (56). However, increased $\lambda$ usage in the $C \delta$-CS lineage might also be due to selection of $\lambda$-utilizing cells. Although it is not a direct indication, increased evidence of $V_{\kappa}$ editing would suggest that the increased $\lambda$ usage might also have been induced by editing. Thus, the $10 \%$ of C $\delta$-CS cells that retained $\kappa$ rearrangements were analyzed for evidence that they had been subjected to editing during primary B cell development.

One indicator of receptor editing commonly considered for analyses of the murine $V_{\kappa}$ locus is the proximity of $V_{K}$ and $J_{\kappa}$ genes used. A distal $\mathrm{V}$-to-distal $\mathrm{J}$ gene-editing rearrangement can delete a more proximal V-to-J gene rearrangement in a "leapfrog" fashion. Thus, evidence of receptor editing is a $\mathrm{VJ}_{\mathrm{K}}$ repertoire skewed to the more distal $V$ and $J$ gene segments. However, due to the presence of many inverted $V_{\kappa}$ genes in the human $\kappa$ locus that rearrange by inversion rather than deletion of the intervening sequence, analysis of the $V_{\kappa}$ repertoire for editing is not necessarily informative. As indicated in Figure $5 \mathrm{~A}, \mathrm{~V}_{\mathrm{K}} 4-1$ (or B3), which is actually the most J-proximal of all $V_{\kappa}$ genes, was significantly over-represented in the C $\delta$-CS cells compared with either memory or naive cells. This finding was not surprising, as $V_{\kappa} 4-1$ was previously found to be over-represented in isolated human $\mathrm{B}$ cells that were in the process of receptor editing (44) and in the lupus $V_{\mathrm{K}}$ repertoire (57). Therefore, we hypothesized that because $V_{\kappa} 4-1$ is the segment most proximal to the $J_{\kappa}$ genes, any primary rearrangement of an upstream inverted $V_{\kappa}$ gene will result in its inversion and availability for secondary, editing rearrangements (Figure 5B). Thus, increased $V_{\kappa} 4-1$ could be indicative of editing. Because $V_{K} 4-1$ is also inverted, as a primary rearrangement product, the $\mathrm{V}_{\mathrm{K}} 4-1$ RSS-to- $\mathrm{J}_{\mathrm{K}}$ RSS junction will be retained in the locus. However, as a secondary (editing) rearrangement occurs after it is first inverted, the $V_{\kappa} 4-1-$ to $-J_{\kappa}$ RSS junction will be lost (Figure $5 B)$. Thus, because of the position of $V_{K} 4-1$ and its orientation in the $V_{\kappa}$ locus, analysis of the genetic configuration of $V_{K} 4-1-$ to- $J_{K} 2$ rearrangements provides a measure of receptor editing for all $V_{K}$ genes. Analysis by semiquantitative PCR indicated that for samples normalized based on $V_{K} 4-1$-to- $J_{K} 2$ rearrangements, relative to that of naive and memory B cells, there was tenfold less of the $V_{\kappa} 4-1$ RSS-to- $\mathrm{J}_{\mathrm{K}} 2$ RSS product in C $\delta$-CS cells and therefore tenfold more editing (Figure 5C). In conclusion, the increased frequency of $\mathrm{V}_{\mathrm{K}} 4-1$-to-Jk2 rearrangements in C $\delta$-CS B cells results from extensive receptor editing. If it is assumed that the more than $90 \% \lambda$ usage is also due to editing, than it would appear that nearly all $\mathrm{B}$ cells that undergo class switch to $C \delta$ were selected for editing during primary B cell development. A second possibility is that the C $\delta$-CS lineage is proficient for receptor editing in peripheral lymphoid tissues, as we have previously reported that from this lineage, $\mathrm{V}$ gene clones can be isolated that have apparently edited their heavy chain $\mathrm{V}$ regions after the onset of somatic hypermutation (10). However, the origin of these recombinations is controversial because it is not clear if the RAG genes can be expressed during a $\mathrm{GC}$ reaction $(58,59)$. Thus, evidence of extensive receptor editing further demonstrates that B cells are probably selected into the $\mathrm{C} \delta$-CS lineage due to encoded Ig autoreactivities.

$J \kappa$ gene usage demonstrates selection of cells that did not require receptor editing to the IgG populations. Because there are only five $\mathrm{J}_{\kappa}$ genes, all situated in the same orientation, unlike the $V_{K}$ repertoire, analysis of $J_{K}$ usage for distal bias provides evidence of receptor editing. There is a bias for distal $\mathrm{J}_{\mathrm{K}}$ utilization in the $\mathrm{C} \delta$-CS population (Figure $5 \mathrm{~A}$ ), and distal $\mathrm{J}_{\mathrm{K}}$ bias was previously reported in B cells in the process of receptor editing (45). Consistent with other analyses herein, both the IgG memory $\left(\mathrm{IgD}^{-} \mathrm{IgG} \mathrm{CD}^{+} 7^{+}\right)$repertoire from two donors and total memory $\left(\mathrm{IgD}^{-} \mathrm{CD} 27^{+}\right)$from two additional donors, which consist of more than $90 \%$ class-switched cells, were dominated by rearrangements to $\mathrm{J}_{\kappa} 1$ (Figure $5 \mathrm{~A}$ ). This is in contrast to the naive cells that utilize the $\mathrm{J}_{\kappa} 1$ through $\mathrm{J}_{\kappa} 4$ genes in an unbiased fashion. Thus, $\mathrm{B}$ cells harboring previously edited immune receptors and thus identified during primary selection as autoreactive are counterselected from the predominantly IgG memory populations.

\section{Discussion}

This report includes an extensive characterization of the expressed human $\mathrm{V}_{\mathrm{H}} \mathrm{DJ} \mathrm{J}_{\mathrm{H}}$ gene repertoire involving simultaneous analysis of many stages of human peripheral B cell differentiation. We found significant changes in $\mathrm{V}$ gene repertoire features correlated with autoimmunity and receptor editing associated mainly with CSR, 
rather than just differentiation to GC or memory B cells and PCs. The repertoire changes characterized included (a) profound selection of $\mathrm{V}_{\mathrm{H}} 4-34$-utilizing $\mathrm{B}$ cells likely due to tolerization against the natural specificity to iI glycans on "self" tissues, as evidenced by selection for mutations of $\mathrm{V}_{\mathrm{H}} 4-34$ to nucleotides encoding the residues involved in iI-glycan binding and hemagglutination; (b) class-related selection of $\mathrm{J}_{\mathrm{H}} 6$ gene segment usage; (c) CDR3 length selection; (d) increased numbers of charged residues in the C $\delta$-CS lineage; and (e) selection of B cells with receptors that were edited during primary selection both into the $C \delta$-CS lineage and out of the IgG memory cell compartment. In fact, there were few significant differences in any of these categories in association with the B cell compartment of a particular isotype pool or between differentiated or somatically mutated versus unmutated $\operatorname{IgM}^{+} \mathrm{B}$ cell clones (see below). Thus, we conclude that selective mechanisms acting on naive and $\operatorname{IgM}^{+} \mathrm{B}$ cells in the periphery, including clonal deletion, anergy (23), follicular exclusion and developmental arrest (24-26), autoimmune "ignorance" $(26,60)$, and a possible novel mechanism proposed below, are predominantly associated with the avoidance of autoreactivities in class-switched B cell populations. This is not to suggest that peripheral selection is not active on $\operatorname{IgM}^{+} B$ cells, but rather that the gross effects of selection on the $\mathrm{V}$ gene repertoire are evident mainly for class-switched B cells. Indeed, part of the observed changes could be due to the high attrition of B cells with IgM receptors (61), leading to a more frequent turnover of the IgM pool on the whole without sustained tolerizing influences, as occurs for longer-lived $\mathrm{IgG}^{+} \mathrm{B}$ cells. This possibility is supported by the finding of a higher level of variance observed for the IgM+ $\mathrm{IC}^{+}$and memory cells compared with IgG pools from various donors: the IgG cells are consistently reduced for the various measures of an autoimmune repertoire studied, whereas IgM populations are more variable. Alternative but not mutually exclusive hypotheses are also possible, given that $\mathrm{B}$ cells that undergo class switch to IgG may have particular sensitivities to tolerizing stimuli, as supported by a recent report of unique selection against $\mathrm{B}$ cells switched to IgG during primary development in a transgenic mouse model (62). In addition, IgG cells can reenter or continue GC reactions, as evidenced by the differential mutations of clonally expanded $\mathrm{IgG}^{+} \mathrm{B}$ cell clones. Thus, to control possible autoreactivites generated by mutations, the $\mathrm{IgG}^{+} \mathrm{GC}$ cells must also continue to be subjected to mechanisms of negative selection.

The reduced mutation frequency of the $\operatorname{IgM}^{+} \mathrm{GC}, \operatorname{IgM}^{+}$memory, and $\mathrm{IgM}^{+} \mathrm{PC}$ populations (Table 3; refs. 3, 28) relative to that of IgG populations might suggest that these populations are heterogenous, derived from a combination of GC-dependent and GC-independent processes. Therefore, as a further control, the $\operatorname{IgM}^{+}$populations were separated into somatically mutated and unmutated fractions from each donor. Both fractions were unchanged for the various criteria studied. Assuming that most (but not all; refs. 60, 63) mutations are generated in GC-dependent processes, this analysis provides further evidence that the $V$ gene repertoire is not significantly altered at the gross level except in association with Ig class. The high attrition rate of $\operatorname{IgM}^{+}$cells relative to class-switched cells (61) could account for the reduced mutation frequency, as the $\operatorname{IgM}^{+}$cells simply do not survive long enough to accumulate mutations. As described herein, the selective pressures on $\mathrm{IgG}^{+}$and $\mathrm{C} \delta$-CS cells appear to be greater than those on $\mathrm{IgM}^{+}$cells, and thus cells from the class-switched pools may have accumulated a greater number of mutations to deal with the more stringent selective criteria. A final possibility that may contribute to the reduced mutation frequency of $\operatorname{IgM}^{+} \mathrm{B}$ cells is that a portion of the cells may continue to differentiate to the GC, memory, or PC phe- notypes after abortive GC reactions $(64,65)$ and thus have less exposure to the mutation machinery. Several recent reports have suggested that inappropriate control of the GC reaction may lead to systemic lupus erythematosus $(66,67)$, and thus disruption of GC reactions may also represent a means of censoring autoreactive $B$ cell clones and contribute to the counterselection from $\mathrm{IgG}^{+}$populations.

It should also be noted that further subdivisions of B cells commonly studied in mice, such as marginal zone B cells and B1 $\left(\mathrm{CD5}^{+}\right)$versus B2 (CD5-) cells, were not considered because these populations are not well characterized in humans. A marginal zone $B$ cell counterpart in humans has been reported to be $\mathrm{IgM}^{+} \mathrm{IgD}^{-} \mathrm{CD} 38^{\text {low }}(68)$ and thus might be a minor contaminant of the IgM GC populations. However, marginal zone B cells in mice have recently been shown to have functional heterogeneity and may be formed of a mixture of plasmablasts and memory cells (69). It has not been ruled out that these marginal zone equivalent cells in humans are heterogenous as well. Use of the CD5 marker to sort $\mathrm{B} 1$ from $\mathrm{B} 2$ cells remains controversial for humans because unlike the situation in mice, CD5 is expressed on a portion of almost all known subdivisions of human B cells, including class-switched populations, and thus we felt this distinction was also beyond the scope of this report. However, it should be noted that there is an intriguing report of a differential repertoire in $\mathrm{IgM}^{+} \mathrm{CD}^{+}$versus $\mathrm{IgM}^{+} \mathrm{CD5}^{-} \mathrm{B}$ cells (70), although the differences noted were modest and that study was based only on two subjects.

Although the $C \delta$-CS lineage may be a specialized differentiation with specific antigenic reactivity giving rise to its unique $V$ gene repertoire, the impressive selection of hallmarks of autoimmunity and evidence of receptor editing suggests that this population arose due to some mechanism of tolerance. We propose that a novel mechanism of tolerance causes the differentiation of these cells and contributes to class-related selection, as naturally occurring or mutationally generated autospecific B cells may become tolerized so that class switch is inhibited. If these autoreactive B cells are strongly activated by foreign antigen with $\mathrm{T}$ cell help or other accessory signals, they become competent to differentiate to GC cells and initiate class switch and somatic hypermutation, except that the class switch to $\mathrm{IgG}$ is blocked. However, these cross-reactive cells may be permitted to undergo class switch from $\mathrm{C} \mu$ to $\mathrm{C} \delta$, possibly because of the cryptic nature of the $C \delta$ switch regions. Alternatively, switch may be actively induced to the $\delta$ switch region as a specialized lineage. In any case, this lineage of cells may represent a specialization that can provide some level of immunity to the activating antigen despite their cross-reactive receptors, as evident by their differentiation to both PCs (7) and memory cells (8). It is notable that the C $\delta$-CS lineage typically represents only a small proportion of total B cells (1\%) but is sometimes expanded to as many as $5 \%$ for some donors (ref. 7 and data not shown). Thus, certain immune responses may be highly dependent on the $\mathrm{C} \delta$-CS response, particularly if the "best" B cell clone activated exhibits a cross-reactive specificity.

Selection of mutations to the amino acid positions involved in the binding of $\mathrm{V}_{\mathrm{H}} 4-34$ gene-encoded antibodies to iI glycans for the $\mathrm{C} \delta$-CS lineage (Figure 2D) suggests that despite the preferential differentiation of autoreactive $\mathrm{B}$ cells to this lineage, the cells must still adhere to some level of tolerance. Thus, we propose that induction of previously tolerized (switch-inhibited) B cells during GC differentiation leads to $\mathrm{C} \mu$-to-C $\delta$ class switch and accumulation of somatic mutations. The intense selection required to select $B$ cells with reduced autoreactivity in addition to continued or increased foreign antigen affinity (specificity) may account for 
both the excessive somatic hypermutation frequency of this population (ref. 9 and Table 3 ) and the high frequency of related clones (10) indicative of only limited survival or input to this lineage. Although it is controversial whether it is RAG mediated or possibly associated with somatic mutation, ongoing receptor editing and $\mathrm{V}_{\mathrm{H}}$ or $\mathrm{V}_{\mathrm{L}}$ chain replacement may also play a role in the tolerization of these clones. We have previously reported that clonally related but differentially mutated $C \delta$-CS-lineage B cells can have portions of their $V_{H}$ genes replaced (10), in addition to the evidence of $V_{K}$ editing reported herein. However, the increased evidence of $\mathrm{V}_{\mathrm{K}}$ editing could just as well represent selection of cells edited during development, as proposed above.

The inhibition of class switch proposed as a new mechanism of IgM cell tolerization could simply be anergy (71) or some degree of anergy. It is known that T cell signals (CD40L and IL-4) can overcome anergy in autoreactive transgenic B cells to induce IgM differentiation and secretion (72). In addition, for a similar model system of anergy, but with the autoreactive V gene "knocked into" the Ig locus rather then as a nontargeted transgene, the same $\mathrm{T}$ cell factors will induce efficient class switch to IgG (73). Thus, classically defined anergy as described by the large body of work using the anti-hen egg lysozyme mouse model would not seem to account for a process of switch inhibition leading to the generation of $\mathrm{C} \mu$-to-C $\delta$ switch. Thus, the possibility exists that there is a mechanism separate from full-blown anergy that inhibits class switch directly for cells with low to moderate self-antigen interaction without disrupting the B cells' participation in an immune response. This leniency in nonswitched $\mathrm{B}$ cells is understandable, as the IgM response is much less prolific and shorter in duration in those cells than in switched cells (61) and the IgM antibodies themselves are generally not as damaging. In fact, the reduced survival of IgM-utilizing B cells after activation may have coevolved with a direct inhibition of class switch as a means of providing opportunity for differentially mutated $\operatorname{IgM}$ variants to overcome their natural autoreactivity and then undergo class switch, but a limited lifespan or specialization by $\mathrm{C} \mu$-to-C $\delta$ switch for those that retain autospecificities.
In conclusion, the demonstration of significant shifts in the $V$ gene repertoire mainly associated with Ig class provides important insight into the overall dynamic of peripheral immune selection resulting from the many mechanisms of tolerance. Both as an additional basic mechanism of tolerance and because of the dangerous potential of a class-switched autoreactive repertoire in autoimmune disease, insight into the control of class switch or tolerizing inhibition of class switch could be of great clinical value for the generation of effective therapeutics. Therefore, we continue to pursue the mechanism leading to preferential switch from $\mathrm{C} \mu$ to $\mathrm{C} \delta$ of $\mathrm{B}$ cells that appear to harbor predominantly autoimmune repertoires. Finally, through antibody expression studies of reactivities "selected into" the $C \delta$-CS population in healthy people, we hope to gain further insight into the types of self antigens to which autoreactive antibodies are naturally "encoded." These analyses are of central importance to the study of autoimmunity, as they provide insight into the initiating autoantigens involved in the breakdown of tolerance that lead to autoimmune disease.

\section{Acknowledgments}

We would like to thank the following: Jacques Banchereau for contributions to the early stages of this work; Sheryl Christopherson and Diana Edwards from the Oklahoma Medical Research Foundation (OMRF) DNA Sequencing facility; The OMRF Imaging facility and staff; Viji Dandapani of the OMRF flow cytometry facility; Todd's Children's Hospital and particularly Sarah Johnson and Jesus Medina for making tonsil specimens available; and Virginia Osbourne and Domenick Nardi for assistance in coordinating with the surgery and pathology departments. Dallas Woodard provided clerical assistance. This work was funded in part by NIH grants P20RR018758-01 (P.C. Wilson), P20RR15577-02 (P.C. Wilson and J.D. Capra), and A112127-29 (J.D. Capra).

Address correspondence to: Patrick Wilson, Molecular Immunogenetics, Oklahoma Medical Research Foundation, 825 NE 13th Street, Oklahoma City, Oklahoma 73104, USA. Phone: (405) 2717393; Fax: (405) 271-8237; E-mail: Patrick-Wilson@omrf.ouhsc.edu.
1. Berek, C., Berger, A., and Apel, M. 1991. Maturation of the immune response in germinal centers. Cell. 67:1121-1129.

2. Jacob, J., Kelsoe, G., Rajewsky, K., and Weiss, U. 1991. Intraclonal generation of antibody mutants in germinal centres. Nature. 354:389-392.

3. Pascual, V., et al. 1994. Analysis of somatic mutation in five B cell subsets of human tonsil. J. Exp. Med. 180:329-339.

4. Liu, Y.J., et al. 1996. Within germinal centers, isotype switching of immunoglobulin genes occurs after the onset of somatic mutation. Immunity. 4:241-250.

5. White, M.B., Word, C.J., Humphries, C.G., Blattner F.R., and Tucker, P.W. 1990. Immunoglobulin D switching can occur through homologous recombination in human B cells. Mol. Cell Biol. 10:3690-3699.

6. Yasui, H., Akahori, Y., Hirano, M., Yamada, K., and Kurosawa, Y. 1989. Class switch from $\mu$ to $\delta$ is mediated by homologous recombination between $\sigma \mu$ and $\sigma \mu$ sequences in human immunoglobulin gene loci. Eur. J. Immunol. 19:1399-1403.

7. Arpin, C., et al. 1998. The normal counterpart of $\mathrm{IgD}$ myeloma cells in germinal center displays extensively mutated IgVH gene, $\mathrm{C} \mu$-C $\delta$ switch, and $\lambda$ light chain expression. J. Exp. Med. 187:1169-1178.

8. Klein, U., Rajewsky, K., and Kuppers, R. 1998. Human immunoglobulin $(\mathrm{Ig}) \mathrm{M}^{+} \mathrm{IgD}^{+}$peripheral blood B cells expressing the CD27 cell surface anti- gen carry somatically mutated variable region genes: CD27 as a general marker for somatically mutated (memory) B cells. J. Exp. Med. 188:1679-1689.

9. Liu, Y.J., et al. 1996. Normal human $\operatorname{IgD}^{+} \operatorname{IgM}^{-}$germinal center B cells can express up to 80 mutations in the variable region of their $\operatorname{IgD}$ transcripts. Immunity. 4:603-613.

10. Wilson, P.C., et al. 2000. Receptor revision of immunoglobulin heavy chain variable region genes in normal human B lymphocytes. J. Exp. Med. 191:1881-1894.

11. Childs, R., and Feizi, T. 1975. Cross idiotypic specificity among heavy chains of macroglobulins with blood group I and i specificities. Nature. 255:562-564.

12. Pascual, V., et al. 1991. Nucleotide sequence analysis of the $\mathrm{V}$ regions of two IgM cold agglutinins. Evidence that the VH4-21 gene segment is responsible for the major cross-reactive idiotype. J. Immunol. 146:4385-4391.

13. Silberstein, L.E., et al. 1991. Variable region gene analysis of pathologic human autoantibodies to the related $\mathrm{i}$ and $\mathrm{I}$ red blood cell antigens. Blood. 78:2372-2386.

14. Pugh-Bernard, A.E., et al. 2001. Regulation of inherently autoreactive VH4-34B cells in the maintenance of human B cell tolerance. J. Clin. Invest 108:1061-1070. doi:10.1172/JCI200112462.

15. Isenberg, D., Spellerberg, M., Williams, W., Griffiths, M., and Stevenson, F. 1993. Identification of the 9G4 idiotope in systemic lupus erythematosus.
Br. J. Rheumatol. 32:876-882.

16. van Vollenhoven, R.F., et al. 1999. VH4-34 encoded antibodies in systemic lupus erythematosus: A specific diagnostic marker that correlates with clinical disease characteristics. J. Rheumatol. 26:1727-1733.

17. Odendahl, M., et al. 2000. Disturbed peripheral B lymphocyte homeostasis in systemic lupus erythematosus. J. Immunol. 165:5970-5979.

18. Yu, K., Taghva, A., and Lieber, M.R. 2002. The cleavage efficiency of the human immunoglobulin heavy chain $\mathrm{VH}$ elements by the RAG complex: implications for the immune repertoire. J. Biol. Chem. 277:5040-5046.

19. Kraj, P., Friedman, D.F., Stevenson, F., and Silberstein, L.E. 1995. Evidence for the overexpression of the VH4-34 (VH4.21) Ig gene segment in the normal adult human peripheral blood B cell repertoire. J. Immunol. 154:6406-6420.

20. Kraj, P., et al. 1997. The human heavy chain Ig V region gene repertoire is biased at all stages of $\mathrm{B}$ cell ontogeny, including early pre-B cells. J. Immunol. 158:5824-5832.

21. Tiegs, S.L., Russell, D.M., and Nemazee, D. 1993. Receptor editing in self-reactive bone marrow B cells. J. Exp. Med. 177:1009-1020.

22. Gay, D., Saunders, T., Camper, S., and Weigert, M. 1993. Receptor editing: an approach by autoreactive B cells to escape tolerance. J. Exp. Med. 177:999-1008.

23. Goodnow, C.C., et al. 1988. Altered immunoglobu- 
lin expression and functional silencing of self-reactive B lymphocytes in transgenic mice. Nature. 334:676-682.

24. Cyster, J.G., Hartley, S.B., and Goodnow, C.C. 1994. Competition for follicular niches excludes self-reactive cells from the recirculating B-cell repertoire. Nature. 371:389-395.

25. Mandik-Nayak, L., Bui, A., Noorchashm, H., Eaton, A., and Erikson, J. 1997. Regulation of anti-doublestranded DNA B cells in nonautoimmune mice: localization to the T-B interface of the splenic follicle. J. Exp. Med. 186:1257-1267.

26. Wang, H., and Shlomchik, M.J. 1999. Autoantigenspecific B cell activation in Fas-deficient rheumatoid factor immunoglobulin transgenic mice. J. Exp. Med. 190:639-649.

27. Wardemann, H., et al. 2003. Predominant autoantibody production by early human B cell precursors. Science. 301:1374-1377.

28. Wilson, P.C., et al. 1998. Somatic hypermutation introduces insertions and deletions into immunoglobulin V genes. J. Exp. Med. 187:59-70.

29. Tangye, S.G., Liu, Y.J., Aversa, G., Phillips, J.H., and de Vries, J.E. 1998. Identification of functional human splenic memory B cells by expression of CD148 and CD27. J. Exp. Med. 188:1691-1703.

30. Arpin, C., et al. 1995. Generation of memory B cells and plasma cells in vitro. Science. 268:720-722.

31. Arpin, C., Banchereau, J., and Liu, Y.J. 1997. Memory $B$ cells are biased towards terminal differentiation: a strategy that may prevent repertoire freezing. J. Exp. Med. 186:931-940.

32. Liu, Y.J., et al. 1995. Memory B cells from human tonsils colonize mucosal epithelium and directly present antigen to $\mathrm{T}$ cells by rapid up-regulation of B7-1 and B7-2. Immunity. 2:239-248.

33. Meffre, E., Casellas, R., and Nussenzweig, M.C. 2001. Antibody regulation of B cell development. Nat. Immunol. 1:379-385.

34. Dono, M., et al. 2000. Heterogeneity of tonsillar subepithelial B lymphocytes, the splenic marginal zone equivalents. J. Immunol. 164:5596-5604.

35. Lefranc, M.P., et al. 1999. IMGT, the international ImMunoGeneTics database. Nucleic Acids Res. 27:209-212.

36. Siminovitch, K.A., Bakhshi, A., Goldman, P., and Korsmeyer, S.J. 1985. A uniform deleting element mediates the loss of $\kappa$ genes in human B cells. Nature. 316:260-262.

37. Potter, K.N., et al. 1993. Molecular characterization of a cross-reactive idiotope on human immunoglobulins utilizing the VH4-21 gene segment. J. Exp. Med. 178:1419-1428.

38. Matsuda, F., et al. 1998. The complete nucleotide sequence of the human immunoglobulin heavy chain variable region locus. J. Exp. Med. 188:2151-2162

39. Brezinschek, H.P., Brezinschek, R.I., and Lipsky, P.E. 1995. Analysis of the heavy chain repertoire of human peripheral B cells using single-cell polymerase chain reaction. J. Immunol. 155:190-202.

40. Wang, X., and Stollar, B.D. 1999. Immunoglobulin $\mathrm{VH}$ gene expression in human aging. Clin. Immunol. 93:132-142.

41. Potter, K.N., Li, Y.C., and Capra, J.D. 1994. The cross-reactive idiotopes recognized by the monoclonal antibodies 9G4 and LC1 are located in framework region 1 of two non-overlapping subsets of human VH4 family encoded antibodies. J. Immunol. 40:43-49.

42. Potter, K.N., Hobby, P., Klijn, S., Stevenson, F.K., and Sutton, B.J. 2001. Evidence for involvement of a hydrophobic patch in framework region 1 of human V4-34-encoded Igs in recognition of the red blood cell I antigen. J. Immunol. 169:3777-3782.

43. Pascual, V., et al. 1992. VH restriction among human cold agglutinins. The VH4-21 gene segment is required to encode anti-I and anti-i specificities. J. Immunol. 149:2337-2344.

44. Meffre, E., et al. 2001. Circulating human B cells that express surrogate light chains and edited receptors. Nat. Immunol. 1:207-213.

45. Meffre, E., Chiorazzi, M., and Nussenzweig, M.C. 2001. Circulating human B cells that express surrogate light chains display a unique antibody repertoire. J. Immunol. 167:2151-2156.

46. Meffre, E., et al. 2003. Surrogate light chain expressing human peripheral B cells produce self-reactive antibodies. J. Exp. Med. 199:145-150.

47. Efremov, D.G., et al. 1996. Restricted immunoglobulin $\mathrm{VH}$ region repertoire in chronic lymphocytic leukemia patients with autoimmune hemolytic anemia. Blood. 87:3869-3876.

48. Elagib, K.E., et al. 1999. Rheumatoid factors in primary Sjogren's syndrome (pSS) use diverse VH region genes, the majority of which show no evidence of somatic hypermutation. Clin. Exp. Immunol. 117:388-394.

49. Ichiyoshi, Y., and Casali, P. 1994. Analysis of the structural correlates for antibody polyreactivity by multiple reassortments of chimeric human immunoglobulin heavy and light chain $\mathrm{V}$ segments. J. Exp. Med. 180:885-895.

50. Klonowski, K.D., Primiano, L.L., and Monestier, M. 1999. Atypical VH-D-JH rearrangements in newborn autoimmune MRL mice. J. Immunol. 162:1566-1572.

51. Link, J.M., and Schroeder, H.W., Jr. 2002. Clues to the etiology of autoimmune diseases through analysis of immunoglobulin genes. Arthritis Res. 4:80-83.

52. Shlomchik, M., et al. 1990. Anti-DNA antibodies from autoimmune mice arise by clonal expansion and somatic mutation. J. Exp. Med. 171:265-292.

53. Radic, M.Z., et al. 1993. Residues that mediate DNA binding of autoimmune antibodies. J. Immunol. 150:4966-4977.

54. Barbas, S.M., et al. 1995. Human autoantibody recognition of DNA. Proc. Natl. Acad. Sci. U. S. A. 92:2529-2533.

55. Hieter, P.A., Korsmeyer, S.J., Waldmann, T.A., and Leder, P. 1981. Human immunoglobulin $\kappa$ lightchain genes are deleted or rearranged in $\lambda$-producing B cells. Nature. 290:368-372.

56. Retter, M.W., and Nemazee, D. 1998. Receptor editing occurs frequently during normal B cell development. J. Exp. Med. 188:1231-1238.

57. Dorner, T., Foster, S.J., Farner, N.L., and Lipsky, P.E. 1998. Immunoglobulin kappa chain receptor editing in systemic lupus erythematosus. J. Clin. Invest. 102:688-694.
58. Yu, W., et al. 1999. Continued RAG expression in late stages of B cell development and no apparent reinduction after immunization. Nature. 12:682-687.

59. Monroe, R.J., et al. 1999. RAG2:GFP knockin mice reveal novel aspects of RAG 2 expression in primary and peripheral lymphoid tissues. Immunity. 11:201-212.

60. William, J., Euler, C., Christensen, S., and Shlomchik, M.J. 2002. Evolution of autoantibody responses via somatic hypermutation outside of germinal centers. Science. 297:2066-2070.

61. Martin, S.W., and Goodnow, C.C. 2002. Burstenhancing role of the $\operatorname{IgG}$ membrane tail as a molecular determinant of memory. Nat. Immunol. 3:182-188.

62. Seagal, J., et al. 2003. A fail-safe mechanism for negative selection of isotype-switched B cell precursors is regulated by the Fas/FasL pathway. J. Exp. Med. 198:1609-1619.

63. Matsumoto, M., et al. 1996. Affinity maturation without germinal centres in lymphotoxin-alphadeficient mice. Nature. 382:462-466.

64. Kelsoe, G. 2003. Therapeutic CD154 antibody for lupus: promise for the future? J. Clin. Invest. 112:1480-1482. doi:10.1172/JCI200320371.

65. Toellner, K.M., et al. 2002. Low-level hypermutation in T cell-independent germinal centers compared with high mutation rates associated with $\mathrm{T}$ cell-dependent germinal centers. J. Exp. Med. 195:383-389.

66. Arce, E., et al. 2001. Increased frequency of pre-germinal center $B$ cells and plasma cell precursors in the blood of children with systemic lupus erythematosus. J. Immunol. 167:2361-2369.

67. Grammer, A.C., et al. 2003. Abnormal germinal center reactions in systemic lupus erythematosus demonstrated by blockade of CD154-CD40 interactions. J. Clin. Invest. 112:1506-1520. doi:10.1172/ JCI200319301.

68. Dono, M., et al. 2000. Heterogeneity of tonsillar subepithelial B lymphocytes, the splenic marginal zone equivalents. J. Immunol. 164:5596-5604.

69. Song, H., and Cerny, J. 2003. Functional heterogeneity of marginal zone $\mathrm{B}$ cells revealed by their ability to generate both early antibody-forming cells and germinal centers with hypermutation and memory in response to a T-dependent antigen. J. Exp. Med. 198:1923-1935.

70. Brezinschek, H.P., et al. 1997. Analysis of the human VH gene repertoire. Differential effects of selection and somatic hypermutation on human peripheral $\mathrm{CD5}^{+} / \mathrm{IgM}^{+}$and $\mathrm{CD}^{-} / \mathrm{IgM}^{+} \mathrm{B}$ cells. J. Clin. Invest. 99:2488-2501.

71. Goodnow, C.C. 1997. Glimpses into the balance between immunity and self-tolerance. Ciba Found. Symp. 204:190-202.

72. Cyster, J.G., and Goodnow, C.C. 1995. Antigeninduced exclusion from follicles and anergy are separate and complementary processes that influence peripheral B cell fate. Immunity. 3:691-701.

73. Phan, T.G., et al. 2003. B cell receptor-independent stimuli trigger immunoglobulin (Ig) class switch recombination and production of IgG autoantibodies by anergic self-reactive B cells. J. Exp. Med. 197:845-860. 